\title{
Ultralow Level Mercury Treatment Using Chemical Reduction and Air Stripping
}

Westinghouse Savannah River Company

Savannah River Site

Aiken, South Carolina 29808

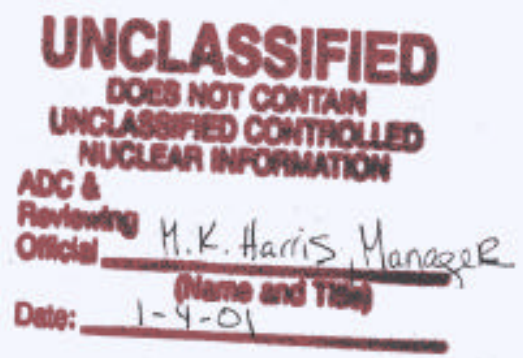

Prepared for the United States Department of Energy under Contract No. DE-AC09-96-SR18500 
This document was prepared in conjunction with work accomplished under Contract No.

DE-AC09-96SR18500 with the U.S. Department of Energy.

\section{DISCLAIMER}

This report was prepared as an account of work sponsored by an agency of the United States Government. Neither the United States Government nor any agency thereof, nor any of their employees, makes any warranty, express or implied, or assumes any legal liability or responsibility for the accuracy, completeness, or usefulness of any information, apparatus, product or process disclosed, or represents that its use would not infringe privately owned rights. Reference herein to any specific commercial product, process or service by trade name, trademark, manufacturer, or otherwise does not necessarily constitute or imply its endorsement, recommendation, or favoring by the United States Government or any agency

thereof. The views and opinions of authors expressed herein do not necessarily state or reflect those of the United States Government or any agency thereof.

This report has been reproduced directly from the best available copy.

Available for sale to the public, in paper, from: U.S. Department of Commerce, National Technical Information Service, 5285 Port Royal Road, Springfield, VA 22161, phone: (800)

553-6847, fax: (703) 605-6900, email: orders@ntis.fedworld.gov online ordering: http://www.ntis.gov/ordering.htm

Available electronically at http://www.doe.gov/bridge

Available for a processing fee to U.S. Department of Energy and its contractors, in paper, from: U.S. Department of Energy, Office of Scientific and Technical Information, P.O. Box 62, Oak Ridge, TN 37831-0062, phone: (865 ) 576-8401, fax: (865) 576-5728, email: reports@ adonis.osti.gov 


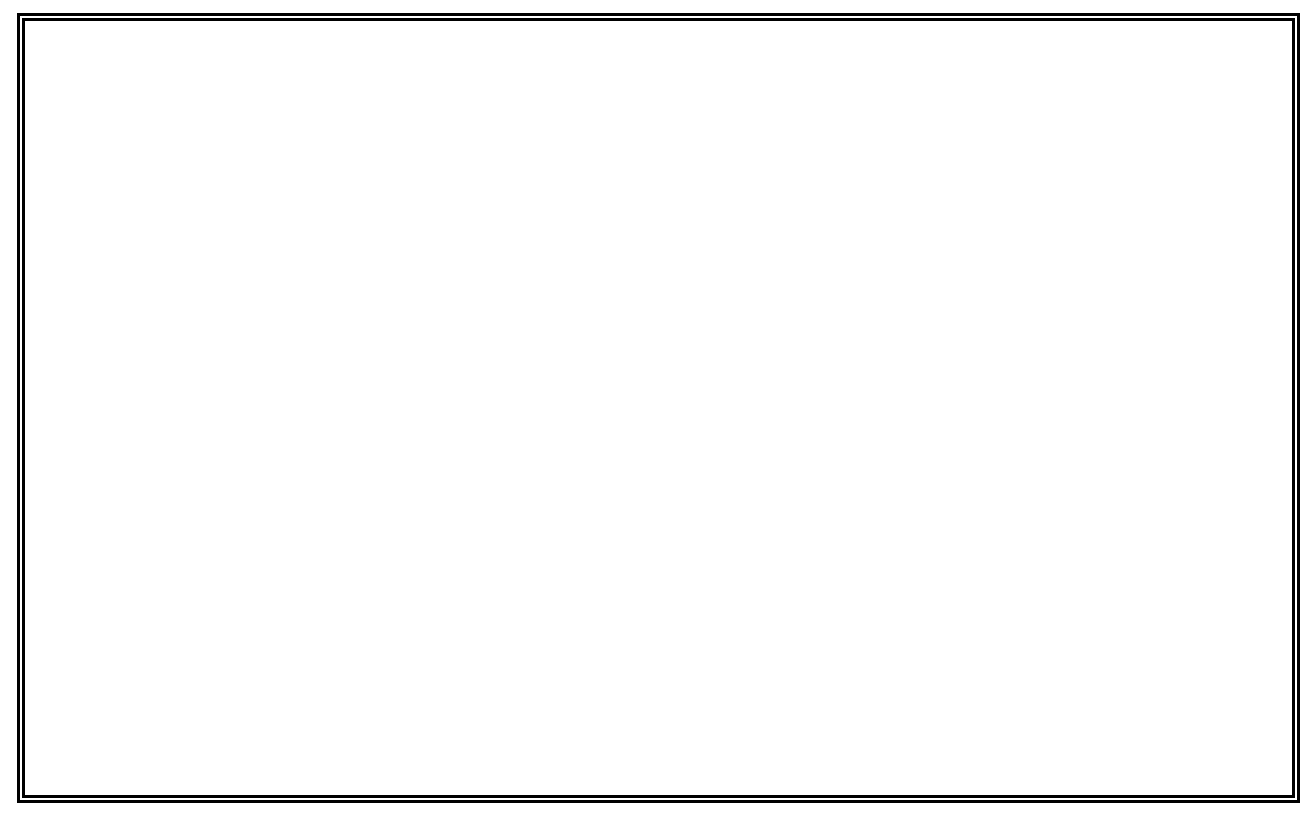

\section{Acknowledgements}

The authors gratefully acknowledge the support of the U.S. Department of Energy, the Savannah River Technology Center and the operating divisions of the Savannah River Site who support the Strategic Research and Development Program. We also recognize the early work of George Southworth (Oak Ridge National Laboratory). We are extending the results of his early studies and appreciate his gracious support and guidance. Finally, we acknowledge the excellent support of the SRTC glassblowers and laboratory technicians. 


\section{Ultralow Level Mercury Treatment Using Chemical Reduction and Air Stripping}

B. B. Looney

M. E. Denham

K. M. Vangelas

J. W. Koch

Environmental Science and Technology

Savannah River Technology Center

Aiken SC 29808

N. S. Bloom

Frontier Geosciences Inc

414 Pontius North

Seattle WA 98109

15 December 2000

Westinghouse Savannah River Company

Savannah River Site

Aiken, South Carolina 29808

Prepared for the United States Department of Energy under Contract No. DE-AC09-96-SR18500 
WSRC-RP-2000-01028

Rev. 0 


\section{Ultralow Level Mercury Treatment Using Chemical Reduction and Air Stripping}

\section{Table of Contents}

Table of Contents

List of Tables $\quad$ v

List of Figures $\quad$ v

Abstract vii

$\begin{array}{lr}\text { Objectives } & 1\end{array}$

$\begin{array}{ll}\text { Background } & 1\end{array}$

Summary Description of Research 2

$\begin{array}{ll}\text { Technical Approach } & 3\end{array}$

Mercury Chemistry 3

Selection of Water for Stage 1 Tests 5

Equipment 6

General Protocol-Dose Response Studies 8

General Protocol - Kinetic Study 8

Analytical 9

$\begin{array}{lr}\text { Results } & 14\end{array}$

$\begin{array}{lr}\text { Engineering Considerations } & 18\end{array}$

$\begin{array}{lr}\text { Scoping Analysis } & 20\end{array}$

$\begin{array}{lr}\text { References } & 21\end{array}$

Appendix A - Dose-Response Study Data 23

Appendix B - Kinetic Study Data $\quad 29$ 
WSRC-RP-2000-01028

Rev. 0 


\section{Ultralow Level Mercury Treatment Using Chemical Reduction and Air Stripping}

\section{List of Tables}

1. Half-cell reactions for tin, mercury, and potential interferences. 5

2. Various conditions tested in Stage 2 Kinetic Study 8

3. Literature values of solubility and vapor pressure used to calculate Henry's Law and theoretical sparge performance 16

4. Compatibility data for materials in contact with high $\begin{array}{ll}\text { concentration stannous chloride solutions } & 19\end{array}$

\section{List of Figures}

1. Relation between the $\mathrm{Sn}(\mathrm{II}) / \mathrm{Sn}(\mathrm{IV})$ redox couple and mercury speciation. 4

2a. Overall schematic of system 6

2b. Detail of bottle/reactor design $\quad 7$

3. Experimental apparatus set up in the field near the A-Area Stripper 10

4. Photograph of (A) gas delivery system and (B) operating sparge vessel 11

5. Miscellaneous photographs of SRTC researchers performing study 12

6. Collection of sample for a kinetic study of mercury-tin reaction rates 13

7. Mercury Treatment - Various Runs Performed at the A-Area Stripper at SRS 14

8. Results of Kinetic Study 17 
WSRC-RP-2000-01028

Rev. 0 


\title{
Ultralow Level Mercury Treatment Using Chemical Reduction and Air Stripping
}

\begin{abstract}
Field, laboratory and engineering data collected during the project confirmed the efficacy of chemical reduction and air stripping/sparging as an ultralow level mercury treatment concept for waters containing $\mathrm{Hg}(\mathrm{II})$. The process consists of dosing the water with low levels of stannous chloride to convert the mercury to $\mathrm{Hg}^{\circ}$. This form of mercury can easily be removed from the water by air stripping or sparging. Samples of Savannah River Site (SRS) groundwater containing approximately $130 \mathrm{ng} / \mathrm{L}$ of total mercury (as $\mathrm{Hg}(\mathrm{II}))$ were used for the field study. In undosed samples, sparging removed $0 \%$ of the initial mercury. Removal in the treated samples varied by dose. Low doses $(<0.0001$ $\mathrm{mg} / \mathrm{L}$ as stannous chloride dihydrate) showed little removal. Reagent doses above 0.01 $\mathrm{mg} / \mathrm{L}$ showed relatively complete removal $(>94 \%)$ - the residual total mercury in all of these samples was reduced to levels below $10 \mathrm{ng} / \mathrm{L}$. Reagent doses between $0.0001 \mathrm{mg} / \mathrm{L}$ and $0.01 \mathrm{mg} / \mathrm{L}$ responded in a regular manner. Mercury removal in this critical range was achieved with doses between 1 and 25 the theoretical minimum stoichiometric amount (for the redox reaction between $\mathrm{Hg}$ (II) and $\mathrm{Sn}$ (II)). In the laboratory, a kinetic study indicated that addition of $\mathrm{Sn}$ (II) results in extremely rapid reduction of $\mathrm{Hg}$ (II) to $\mathrm{Hg}(0)$. For all of the $\mathrm{Sn}(\mathrm{II})$ addition experiments, the mercury removal rate from solution appeared to be controlled by the purging process rather than the mercury conversion rate. In general, the data indicate that the reduction of mercury is highly favored and that stannous chloride reagent efficiently targets the $\mathrm{Hg}$ (II) contaminant in the presence of competing reactions. Based on the results, we estimated that the costs of implementing and operating an ultralow level mercury treatment process based on chemical reduction and stripping/sparging are competitive with traditional treatment technologies. For a hypothetical $200 \mathrm{gpm}$ system, capital costs ranged from $\$ 50,000$ to $\$ 250,000$ and

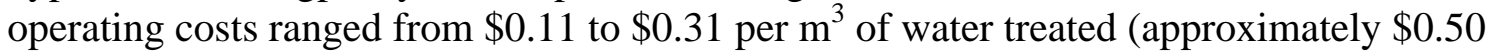
to $\$ 1.50$ per 1000 gallons). This project was supported by the Savannah River Technology Center (SRTC) Strategic Research and Development Program.
\end{abstract}


WSRC-RP-2000-01028

Rev. 0 


\section{Ultralow Level Mercury Treatment Using Chemical Reduction and Air Stripping}

\section{Objectives}

The overall objective of this work is to develop a reasonable and cost-effective approach to meet the emerging mercury standards, especially for high volume outfalls with concentrations below the drinking water standard (DWS). The specific objectives of the various tasks are to determine the efficacy and practicality of treating aqueous mercury to $\mathrm{ng} / \mathrm{L}$ levels using a combination of chemical reduction (to $\mathrm{Hg}^{0}$ ) followed by stripping/sparging.

\section{Background:}

Over the past ten years the Environmental Protection Agency (EPA) has developed a policy aimed at elimination of mercury emissions. This policy has been articulated in the PBT (Persistent, Bioaccumulative and Toxic) Pollutants Program, the White House Clean Water Action Plan, the Mercury Report to Congress, the executive order for federal agency assessments of risks to children, and the U.S.-Canada Bilateral Toxics Agreement. In each case, mercury was identified as the most significant contaminant and specific actions to reduce and/or eliminate mercury were required. Proposed ecological protection mercury standards are well below drinking water standards and are so low that new analytical methods have been developed and were approved in 1999 (EPA method 1631). Carol Browner of the EPA recently announced a plan to eliminate dilution from mixing calculations in permitting some National Pollutant Discharge Elimination System (NPDES) outfalls, primarily to meet mercury commitments made in the US-Canada Bilateral Toxics Agreement. A policy of regulating mercury to ultralow levels may affect many outfalls at SRS and will impact industry, municipalities and other government agencies. New water treatment approaches are needed. To be viable, these approaches must treat large volumes of water containing trace levels of mercury in the presence of other ions at a unit cost that is below conventional metals removal methods.

In South Carolina, the Department of Health and Environmental Control (SCDHEC) has indicated that future discharge permits will be based on ambient water quality criteria (AWQC). The current AWQC is $12 \mathrm{ng} / \mathrm{L} \mathrm{--} \mathrm{a} \mathrm{level} \mathrm{that} \mathrm{is} \mathrm{near} \mathrm{background}$ concentration, approximately one tenth of traditional detection limits, and approximately one hundredth of DWS. Draft surface water protection standards (e.g., those currently proposed by EPA for Total Daily Maximum Load (TMDL) in the Savannah River) are even lower -1 to $3 \mathrm{ng} / \mathrm{L}$. A challenge for large facilities such as the Savannah River Site (SRS) is developing reasonable and cost-effective approaches to meet the emerging standards, especially for high volume outfalls with concentrations below the DWS (currently $2000 \mathrm{ng} / \mathrm{L}$ ). The mercury issue has been identified as a substantive issue in setting limits for the A-01 Outfall at SRS. 
SRS has formed a task team to identify traditional commercial treatment options for metals. Unfortunately, traditional treatments typically cost approximately $\$ 1$ to $\$ 2$ per $\mathrm{m}^{3}$ of water ( $\$ 5$ to $\$ 10$ per 1000 gallons). This is equivalent to a cost of more than $\$ 1,000,000 /$ year for a $2 \mathrm{~m}^{3} / \mathrm{min}(400 \mathrm{gpm})$ outfall. We are examining an alternative treatment method. This approach is a modification of analytical methods for mercury in which stannous chloride is used to rapidly convert inorganic mercury into volatiledissolved metallic mercury. The inorganic mercury is removed from the water using air stripping or air sparging. Such a system consists of a reagent infusion pump (or system), a mixing zone, and an air-water contactor (e.g., stripper). If successful, the system would be widely applicable because it would cost much less than traditional water treatment methods. Analytical methods typically employ a large stoichiometric excess of stannous ion but the literature hints that lesser quantities are sufficient. Development of this treatment system requires answering a few key scientific questions (stoichiometry, robustness, etc.) and developing a prototype to show that reliable long-term operation can be achieved. These research questions and objectives are listed and discussed below.

\section{Summary Description of Research}

The basis for this project is the chemistry embodied in various analytical methods for mercury. In these methods, inorganic mercury is reduced to $\mathrm{Hg}^{0}$ using stannous (tin) chloride. $\mathrm{Hg}^{0}$ is volatile and can be removed from the water by simple air-water contact. In the lab, a small sparge is used to strip the mercury into an analyzer. For treatment, air stripping, spraying, or sparging are examples of inexpensive methods applicable to large water volumes. The reaction of tin and inorganic mercury is rapid and thermodynamically favored. Nonetheless, tin-based analytical methods rely on using significant excess reagent to assure that the reaction is complete. Research by Southworth (1996) suggested that tin levels that are only 4 to 5 times stoichiometry may convert the available inorganic mercury to $\mathrm{Hg}^{0}$. This stoichiometry, under one particular set of water chemistry conditions, suggests that the mercury-tin reaction is relatively specific. These ratios also indicate that treatment is possible using tin concentrations that are well within safe-protective levels for both ecological and human health. Further, the research documented that the strippability of the resulting $\mathrm{Hg}^{0}$ is predictable and that required air-water ratios are favorable (e.g., ratios less than 20 provide good removal). The proposed work will attempt to confirm the concept and support practical application.

The research was conducted in two stages: (1) Scoping Studies and (2) Proof of Principle. This report documents the successful completion and results for both stages.

The Studies were performed using "real-world" water collected from groundwater wells. We selected this water, with a nominal concentration near $150 \mathrm{ng} / \mathrm{L}$, to represent a potential SRS treatment need. In Stage 1 we treated the water with a range of stannous chloride concentrations. We sparged each sample using ultraclean equipment and an excess air-water ratio of approximately 30 to 1 . The resulting samples were sealed and sent for total mercury analysis in the laboratory using cold vapor atomic fluorescence 
spectrometry. We collected a large $5 \mathrm{~L}$ sample for a kinetic study to further examine the reaction and mixing times needed. The kinetic study and further tests of treatment effectiveness (at lower tin doses) were completed during Stage 2 of the project. Also in Stage 2, design criteria and equipment options were evaluated to support future full-scale implementation. The overall objective of the Stage 2 was to support long-term design simplicity and robustness (reagent stability, equipment longevity and performance, and the like). All work was performed in accordance with the original test plan (Vangelas, 2000) and is documented in a project specific laboratory notebook (Looney, 2000). Based on the results of the Scoping Studies, we will assemble a prototype treatment system during Stage 2.

\section{Technical Approach}

\section{Mercury Chemistry}

The chemistry of mercury in the environment is complicated by multiple redox states, a tendency to form complex ions, and potential biological transformations. Mercury can exist naturally as the elemental form (zero valent), a univalent form $[\mathrm{Hg}(\mathrm{I})]$, and a divalent form $[\mathrm{Hg}(\mathrm{II})]$. The univalent form occurs predominantly in solid phases such as calomel $\left(\mathrm{Hg}_{2} \mathrm{Cl}_{2}\right)$, but typically dissociates into the elemental and divalent forms when in solution. $\mathrm{Hg}(\mathrm{II})$ has a strong tendency to form complex ions with hydroxyls, chloride, and other common anions. The relative stability of these complexes varies with parameters such as $\mathrm{pH}$ and thus, understanding the chemistry of the solution is important to remediation design. Under moderately reducing conditions $\mathrm{Hg}$ (II) can be converted to elemental mercury. In this redox state mercury can co-exist as liquid metal, vapor, and aqueous solute. Under more reducing conditions where sufficient organic matter is present, microbiological transformations of mercury to methylated forms can occur. These species are the most toxic forms of mercury and are mobile in the environment. However, most groundwater at the Savannah River Site contains very little, if any, methylated mercury (Denham et al, 1999).

Figure 1 shows the relationship between the $\mathrm{Sn}(\mathrm{II}) / \mathrm{Sn}(\mathrm{IV})$ couple and the speciation of mercury in aqueous solution. In highly oxidized natural waters (above a $\mathrm{pE}$ of approximately 8), mercury occurs as $\mathrm{Hg}(\mathrm{II})$, typically as a chloride or hydroxide complex. That the equal activity line of the $\mathrm{Sn}(\mathrm{II}) / \mathrm{Sn}$ (IV) couple is located within the field of dominance of elemental mercury indicates that $\mathrm{Sn}$ (II) will reduce $\mathrm{Hg}$ (II) to elemental mercury. This occurs by the following reaction:

$$
\mathrm{HgCl}_{2}{ }^{\mathrm{o}}+\mathrm{Sn}^{+2}=\mathrm{Hg}^{\mathrm{o}}+2 \mathrm{Cl}^{-}+\mathrm{Sn}^{+4}
$$

Thus, when sufficient stannous chloride is added to water containing dissolved $\mathrm{Hg}$ (II) virtually all $\mathrm{Hg}$ (II) is reduced to elemental mercury. Importantly, mercury occurs primarily as $\mathrm{Hg}(\mathrm{II})$, and its complexes, in most natural waters, even water where $\mathrm{Hg}^{\mathrm{o}}$ is thermodynamically predicted (e.g., $\mathrm{pE}<8$ ). In these systems, the reaction with tin facilitates the transformation of the $\mathrm{Hg}$ (II) to the expected zero valence oxidation state. 
In all cases, the stannous ion must be added in sufficient quantity that a 1:1 $\mathrm{Hg}: \mathrm{Sn}$ stoichiometry is available in the presence of competing redox reactions.

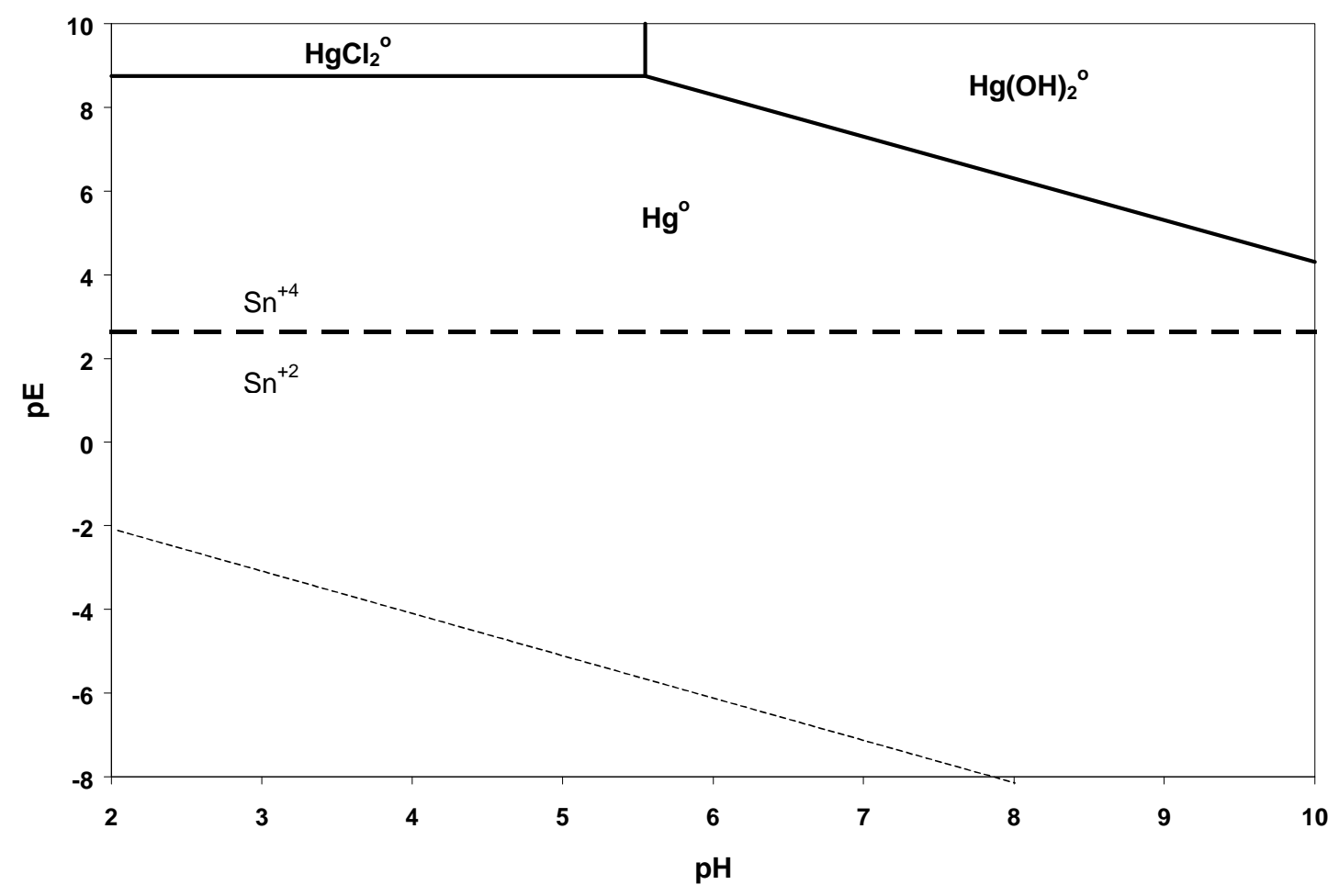

Figure 1: Relation between the $\operatorname{Sn}(I I) / S n(I V)$ redox couple and mercury speciation. $\left[\mathrm{Cl}^{-}\right]=2 \mathrm{mg} / \mathrm{L}$. The coarse dashed line shows the boundary between $\mathrm{Sn}(\mathrm{II})$ and $\mathrm{Sn}(\mathrm{IV})$ fields of dominance. The fine dashed line represents the lower stability limit of water.

The remediation technology being tested exploits the redox chemistry of mercury and the relatively high vapor pressure of elemental mercury. Stannous chloride $\left(\mathrm{SnCl}_{2}\right)$ is used to reduce dissolved divalent mercury to elemental mercury. The dissolved elemental mercury is then stripped from solution by air sparging. Stannous chloride will also reduce other dissolved constituents such as oxygen, nitrate, and contaminants such as trichloroethylene (TCE). Table 1 shows the Standard Potential of the $\mathrm{Sn}$ (IV)/Sn(II) halfcell reaction relative to the mercury couple and to other potential interfering constituents. Oxygen and nitrate are typically present in groundwater at concentrations that are much greater than concentrations of mercury. Likewise, in groundwater contaminated with TCE, mercury concentrations may be small compared to TCE concentrations. The high concentrations of these constituents relative to mercury may require use of a higher concentration of stannous chloride than needed for stoichiometric reduction of mercury. 
WSRC-RP-2000-01028

Rev. 0

Page 5 of 38

Table 1: Half-cell reactions for tin, mercury, and potential interferences. Standard Potentials are in volts vs. the Standard Hydrogen Electrode (SHE).

\begin{tabular}{|l|l|}
\hline Half-cell Reaction & Standard Potential vs. SHE (volts) \\
\hline $\mathrm{Sn}^{+4}+2 \mathrm{e}^{-}=\mathrm{Sn}^{+2}$ & 0.16 \\
\hline $\mathrm{C}_{2} \mathrm{HCl}_{3}(\mathrm{TCE})+\mathrm{H}^{+}+2 \mathrm{e}^{-}=\mathrm{C}_{2} \mathrm{H}_{2} \mathrm{Cl}_{2(1,1-\mathrm{DCE})}+\mathrm{Cl}^{-}$ & 0.54 \\
\hline $\mathrm{NO}_{3}^{-}+2 \mathrm{H}^{+}+2 \mathrm{e}^{-}=\mathrm{NO}_{2}^{-}+\mathrm{H}_{2} \mathrm{O}$ & 0.83 \\
\hline $\mathrm{Hg}^{+2}+2 \mathrm{e}^{-}=\mathrm{Hg}$ & 0.85 \\
\hline $\mathrm{O}_{2(\mathrm{a})}+4 \mathrm{H}^{+}+4 \mathrm{e}^{-}=2 \mathrm{H}_{2} \mathrm{O}$ & 1.27 \\
\hline
\end{tabular}

\section{Selection of Water for Stage 1 and Stage 2 Dose-Response Tests}

We used "real-world" samples for the stage 1 tests. In selecting the source of contaminated water, we reviewed outfalls and wells at SRS. The primary criteria for the selection were:

1) concentrations of mercury should be well characterized and stable,

2) concentrations of mercury should be elevated above background but less than DWS,

3) water from the selected source should be accessible for sampling and study,

4) mercury in the water should be primarily in the form of $\mathrm{Hg}$ (II), and

5) if possible, the water should discharge to a surface water outfall and represent a possible future treatment target.

Based on these criteria, we selected the influent and effluent of the A-Area stripper for the work. The source of the water is groundwater remediation wells located in the northern sector of A/M Area near SRTC. The feed and effluent of the air stripper have been well characterized and provide a very stable source of water that contains between approximately 120 and $150 \mathrm{ng} / \mathrm{L}$ total mercury -- concentrations that are ideal for the scoping study. Previous speciation studies on these waters indicated that almost all of the mercury is $\mathrm{Hg}(\mathrm{II})$. Interestingly, since an air stripper is already in place, the measured concentrations indicate that mercury is not being removed by this unit operation without the benefit of reagent addition. The use of both feed and effluent water provides an interesting comparison of stannous chloride effectiveness in the presence of varying competing reactions (the feed contains significant levels of chlorinated organic solvents and the feed and effluent both contain dissolved oxygen). Finally, a run was performed on A-Area Stripper feed water that was pre-sparged with nitrogen to remove both dissolved oxygen and volatile organic compounds to evaluate the optimum theoretical performance of the treatment method. The effluent from the A-Area Stripper discharges to the A-01 Outfall and represents a significant fraction of the outfall flow volume. Thus, the stripper represents a potential treatment target if ultralow level outfall standards are promulgated. 


\section{Equipment}

Figures $2 \mathrm{a}$ and $2 \mathrm{~b}$ are drawings of the equipment setup used for the dose-response study. The ultra-low levels of mercury in the samples required using materials that do not contain mercury and will not absorb mercury from their surroundings. Furthermore, to be compatible with EPA cleaning protocol, equipment materials should be stable in hot $\left(70^{\circ} \mathrm{C}\right)$ hydrochloric acid. The majority of the equipment was composed of glass, teflon, polypropylene or polyvinylidene difluoride (PVDF) which meet these various requirements. In general, the project used nonmetallic components when possible.

We performed all sample preparation and manipulation inside a field glovebox. We used the glovebox to minimize the possibility of contaminating the samples from outside sources and to protect the reagents from the air.

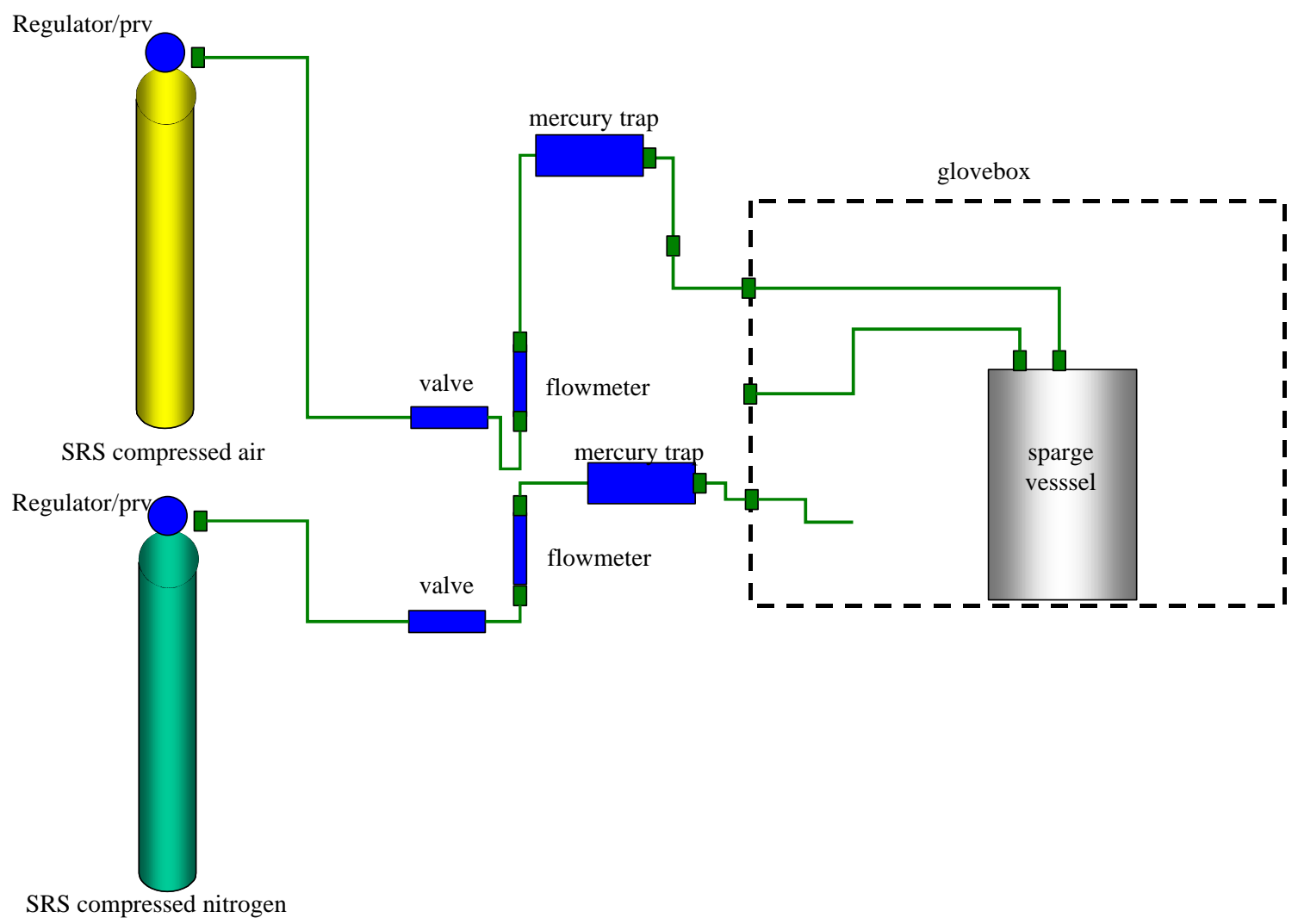

Figure 2a. Overall schematic of system 
Rev. 0

Page 7 of 38

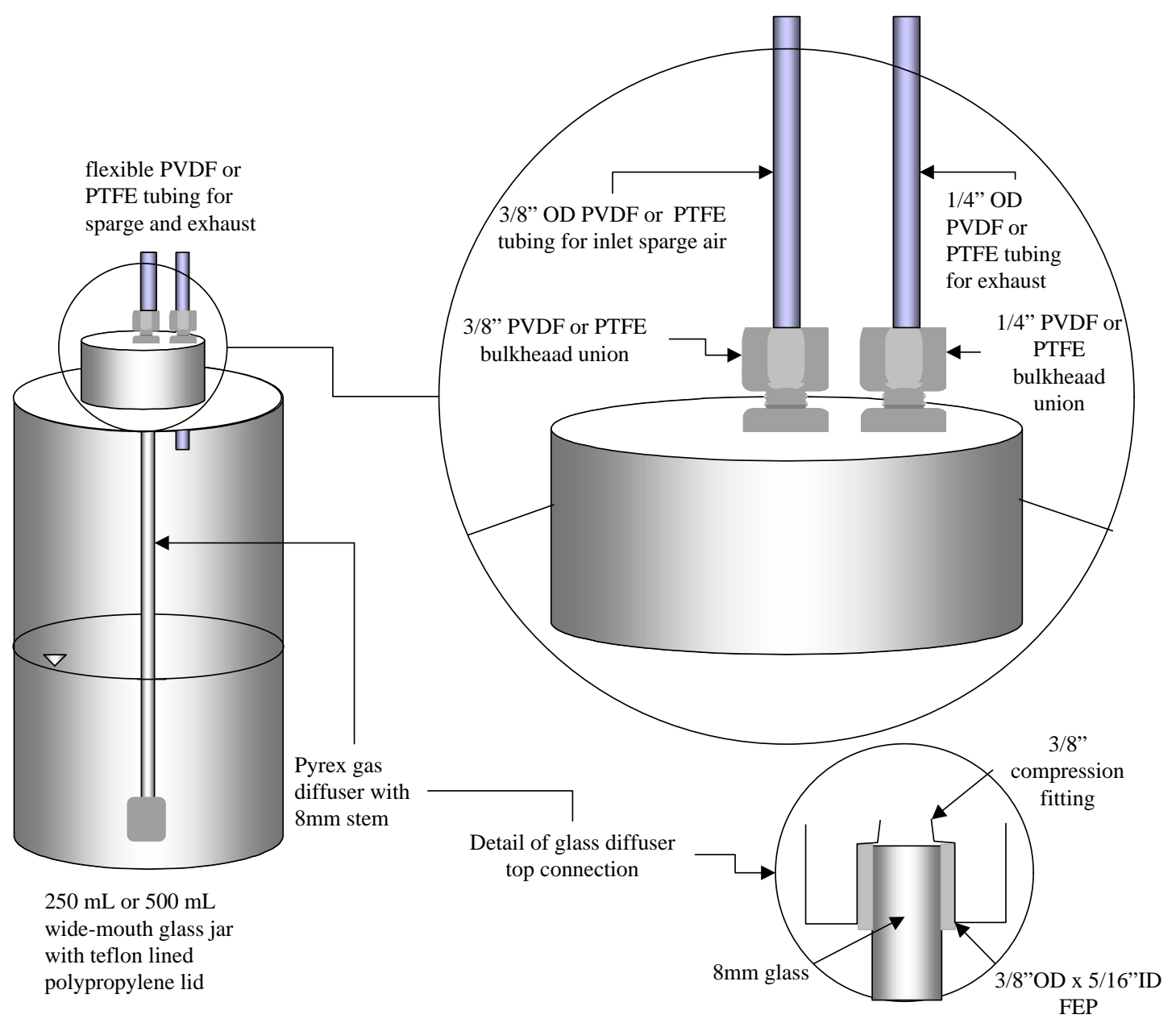

Figure 2b. Detail of bottle/reactor design 
The Stage 1 experiments evaluated the response of mercury concentration in a treated sample to the stannous chloride dosage. Prior to Stage 1, a blank run was performed on every cleaned sparge vessel as a QA step. This blank run was followed by an experimental run that tested stannous chloride dosages from 0 to approximately $800 \mathrm{mg} / \mathrm{L}$ (doses expressed in terms of stannous chloride dihydrate). The doses, along with the effectiveness results, are tabulated in Appendix A. During Stage 1 we tested doses of 0 $\mathrm{mg} / \mathrm{L}, 0.003 \mathrm{mg} / \mathrm{L}, 0.15 \mathrm{mg} / \mathrm{L}, 1.54 \mathrm{mg} / \mathrm{L}, 76.6 \mathrm{mg} / \mathrm{L}$, and $766 \mathrm{mg} / \mathrm{L}$. Because of the relatively high treatment efficiency observed for doses greater than $0.003 \mathrm{mg} / \mathrm{L}$ we examined lower doses in Stage 2: $0.000000616 \mathrm{mg} / \mathrm{L}, 0.00000616 \mathrm{mg} / \mathrm{L}$, and 0.000308 $\mathrm{mg} / \mathrm{L}$ (with replication of $0 \mathrm{mg} / \mathrm{L}$ and $0.003 \mathrm{mg} / \mathrm{L}$ ). The protocol allowed study of doses at basic science and practical engineering levels and extended up to the actual high dosages used in the 1631 analytical method. All Stage 1work was performed in the field in a glove box set up near the A-Area Stripper. Stage 2 work was performed in the glovebox set up in a nearby support laboratory (704D). Figures 3 through 5 are photographs of the field operations.

\section{General Protocol - Kinetic Study}

A separate study was performed during Stage 2 to confirm that the reaction was sufficiently rapid and complete to be practical. This study was performed in the laboratories of Frontier Geosciences in Seattle WA to allow rapid subsampling following dosing and to avoid any possible artifacts associated with dosing and shipping. The study was designed to collect the gas phase reaction product $(\mathrm{Hg}(0))$ as it was generated and sparged from the system. A range of concentrations, doses and temperatures were examined (Table 2).

Table 2. Various conditions tested in Stage 2 Kinetic Study

\begin{tabular}{|c|c|c|c|c|c|}
\hline Run No. & $\begin{array}{c}\text { Sample } \\
\text { Matrix }\end{array}$ & $\begin{array}{c}\text { Total } \\
\text { Mercury } \\
(\mathbf{n g} / \mathbf{L})\end{array}$ & $\begin{array}{c}\text { Temperature } \\
\text { (degrees C.) }\end{array}$ & $\begin{array}{c}\text { Stannous } \\
\text { chloride } \\
\text { dose } \\
\text { (mg/L as } \\
\text { dihydrate) } \\
\text { (note a) }\end{array}$ & pH \\
\hline \hline 1 (note b) & DI water & 100 & 22.8 & 760 & 0.9 \\
\hline 2 & DI water & 100 & 0 & 0 & 5 \\
\hline 3 (note c) & groundwater & 138 & 22.8 & 0.019 & ambient \\
\hline 4 & groundwater & 138 & 22.8 & 0 & \\
\hline 5 & groundwater & 138 & 22.8 & 0.0076 & \\
\hline 6 & groundwater & 138 & 22.8 & 0.0019 & \\
\hline
\end{tabular}

Notes:

$\mathrm{a}=$ original dosing data from Frontier Geosciences were reported in terms of $\mathrm{ug} / \mathrm{L}$ as $[\mathrm{Sn}(\mathrm{II})]$; these were converted for consistency with the remainder of this report $\mathrm{b}=$ these are the same conditions as EPA Method 1631. DI water $=$ deionized water. $\mathrm{c}=$ ambient $\mathrm{pH}$ approximately 5 
The following is a summary excerpt of the full kinetic study report that is provided in Appendix B. Figure 6 shows collection of a 5L sample in a precleaned teflon container for the kinetic study. The $5 \mathrm{~L}$ sample of "groundwater" (effluent water from the A Area stripper) was received on August 8, 2000 and stored at 0 C. and in darkness for 4 days prior to the actual experiment. Purging experiments were conducted in acid cleaned 500 $\mathrm{mL}$ borosilicate gas washing bottles. Each bottle had a total volume of $575 \mathrm{~mL}$ and was charged with $500 \mathrm{~mL}$ of aqueous sample for each experiment. After dosing with stannous chloride, each sample was purged with ultrapurified nitrogen at a flow rate of $220 \mathrm{~mL} / \mathrm{min}$. $\mathrm{Hg}(0)$ evaded from the sample was collected on freshly blanked gold coated quartz sand traps (the same traps used in performing EPA analytical method 1631). Based on the gas flow rate and water volume, the purge rate with regard to the aqueous sample was 0.38 volumes/min. The samples were each purged for a total of 60 minutes. All of the stripped $\mathrm{Hg}(0)$ was collected on sequential gold/sand traps. In general, the traps were collected in 5-minute increments (or composited to 5 minute increments for reporting as discussed in Appendix B). Each 5-minute increment represents an air-water ratio of 1.9. In addition to the experimental runs, two blank runs were performed. For the blank runs, all of the $\operatorname{Hg}(0)$ collected during a 60 minute purging of mercury free reagent water was collected. These runs indicated a very small procedural blank of $0.0006 \mathrm{ng} /$ minute - this value was subtracted from the raw results prior to final tabulation and further calculation. To provide an overall mass balance and assure experimental quality, samples of the bulk solution before and after the purging period were collected for each run. The mass balances (recovery of evaded mercury plus residual mercury in the reaction vessel) for all of the runs ranged from $85 \%$ to $109 \%$. Additionally, the initial groundwater sample was analyzed specifically for $\mathrm{Hg}$ (II) (in addition to total mercury) to help interpret the sparging data. To simplify the analysis and calculations presented below, mercury removals are expressed in terms of actual mercury recovered in each run.

\section{Analytical}

EPA method 1631 (total mercury method described below) was used for analysis of samples for this work. A recognized and experienced ultralow level mercury analysis laboratory (Frontier Geosciences, Seattle WA) was chosen to support this research. Nicholas Bloom of Frontier Geosciences was a principal contributor to the development of EPA Method 1631. He and his staff provided sample containers, bottle cleaning, quality assurance and other support under a subcontract to SRTC.

Aqueous samples were oxidized in their original bottles by the addition of $1.0 \%(\mathrm{v} / \mathrm{v})$ of $0.2 \mathrm{~N} \mathrm{BrCl}$ in $12 \mathrm{~N} \mathrm{HCl}$. A 50 to $125 \mathrm{~mL}$ aliquot of the acidified sample was then placed into a clean teflon bottle and the excess $\mathrm{BrCl}$ oxidant was pre-reduced by the addition of $\mathrm{NH}_{2} \mathrm{OH}$. The pre-reduced solution was then poured into the purge vessel and $\mathrm{SnCl}_{2}$ was added to reduce the free $\mathrm{Hg}(\mathrm{II})$ to elemental $\mathrm{Hg}(0)$. The elemental mercury was purged from the solution and collected on a gold-coated sand trap. After collection, the mercury on the gold trap was collected and "refocused" onto a second "analytical" trap by rapid desorption into a gas stream of pure argon. Finally, the mercury was desorbed from the analytical trap into the cold vapor atomic fluorescence spectrometer (CVAS) cell where it 
was detected and quantified. For these analyses, QA steps included: determining the detection limit and standard curve, analyzing a certified reference material, and analyzing at least three method blanks for every 20 samples. All of the analytical results are tabulated in Appendix A and Appendix B.
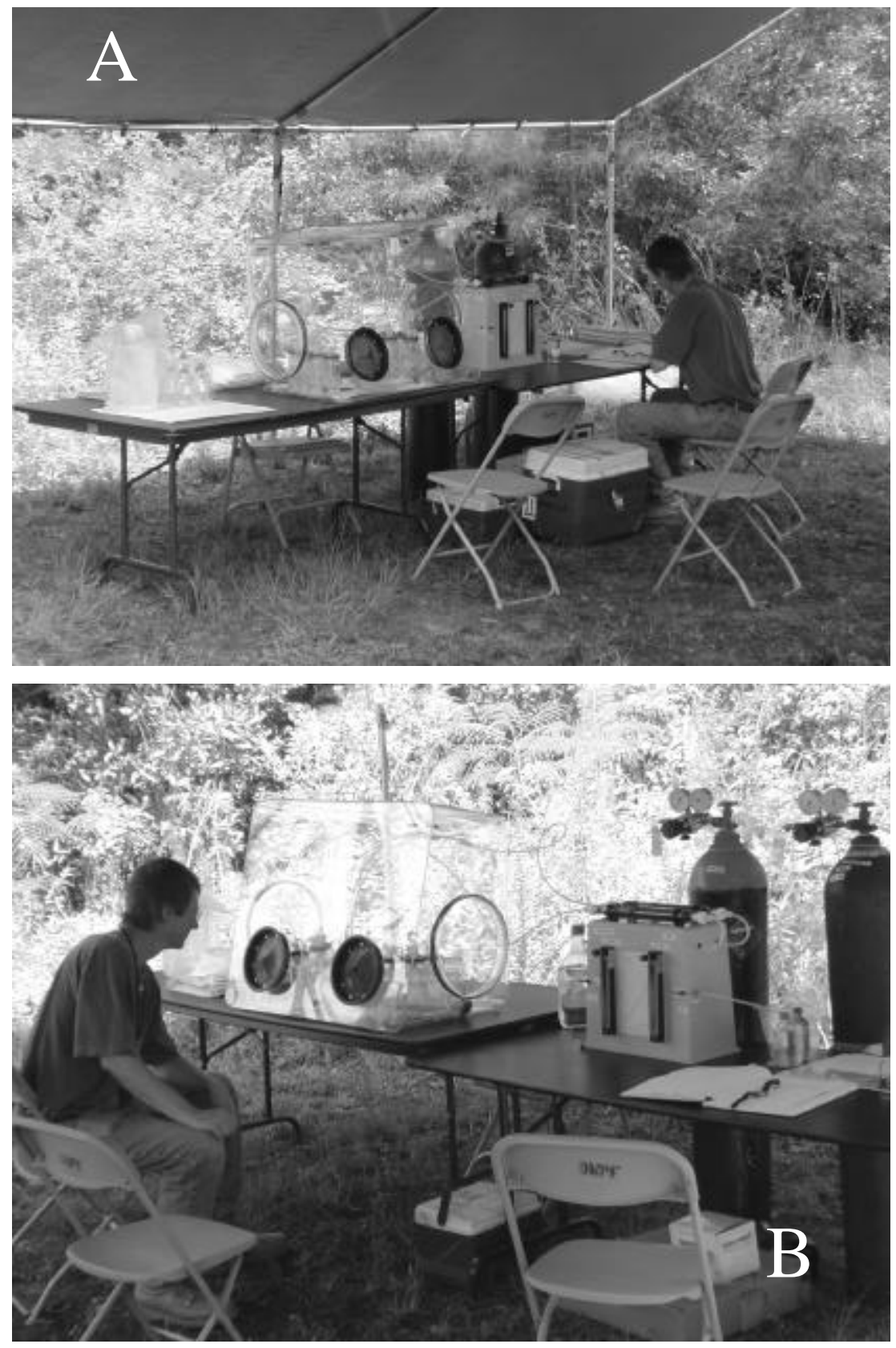

Figure 3: Experimental apparatus set up in the field near the A-Area Stripper. Photographs show (A) general set up and (B) arrangement of glovebox and support equipment 

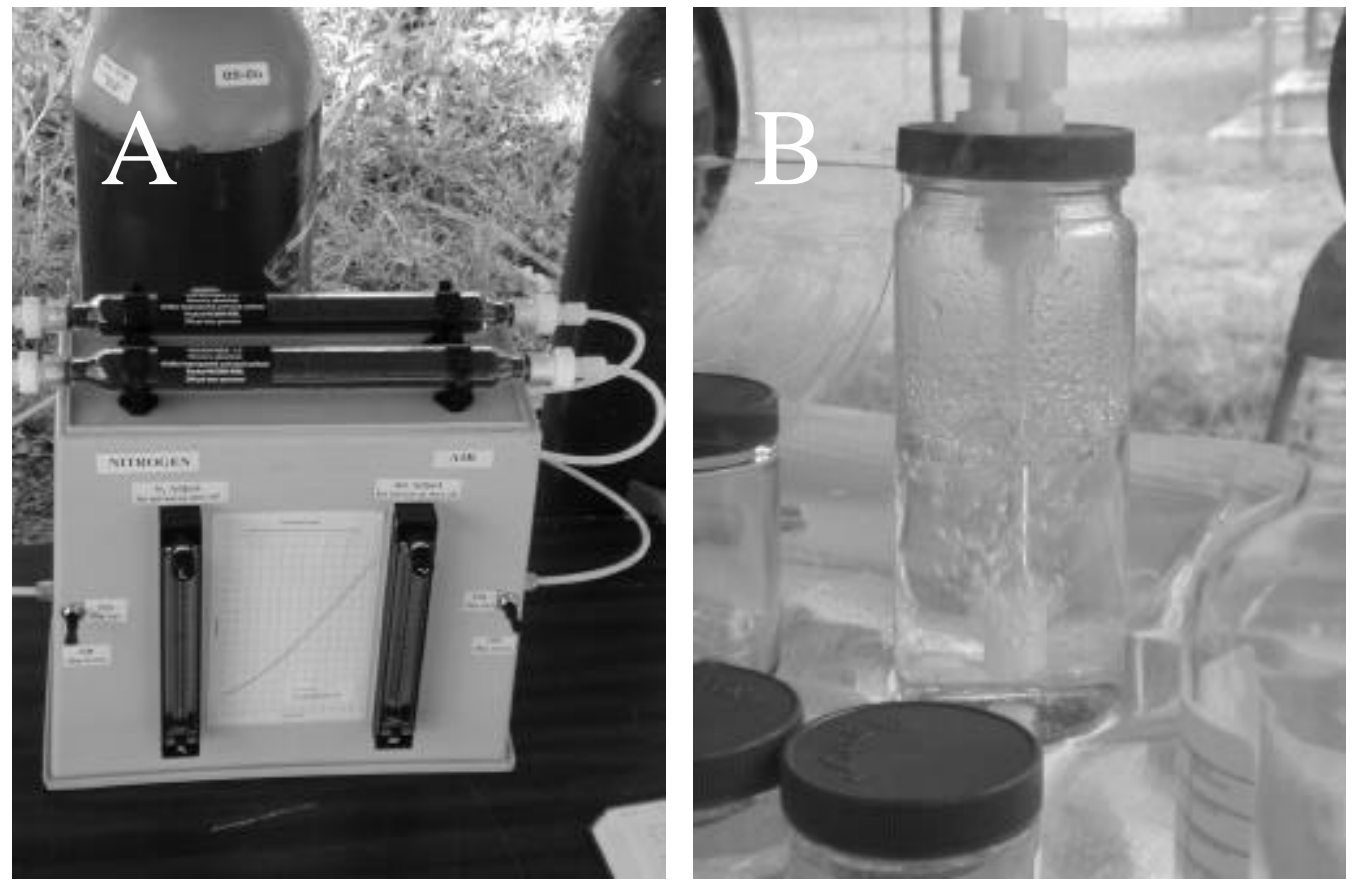

Figure 4: Photograph of (A) gas delivery system and (B) operating sparge vessel 
Rev. 0

Page 12 of 38

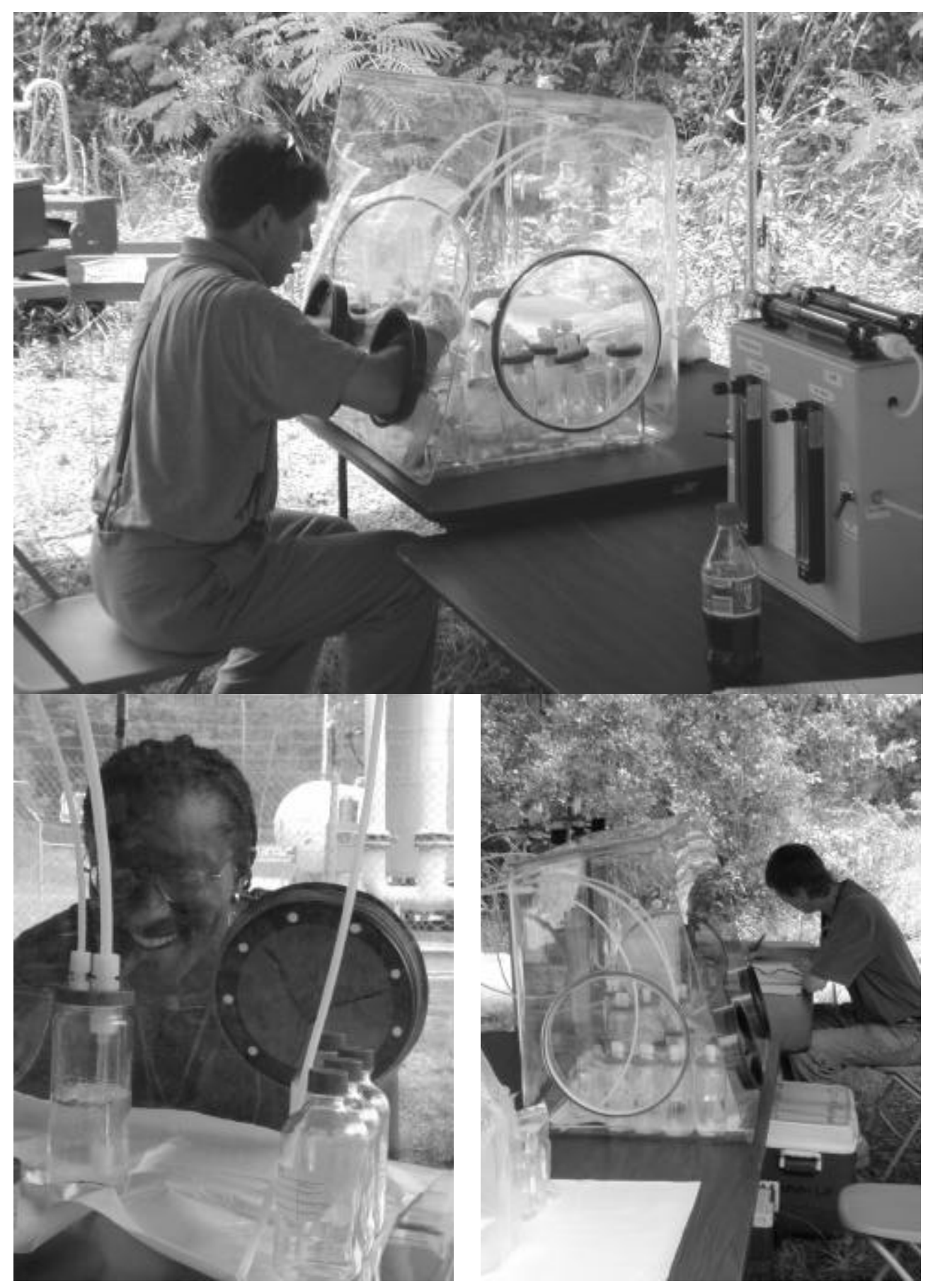

Figure 5: Miscellaneous photographs of SRTC researchers performing study 
WSRC-RP-2000-01028

Rev. 0

Page 13 of 38

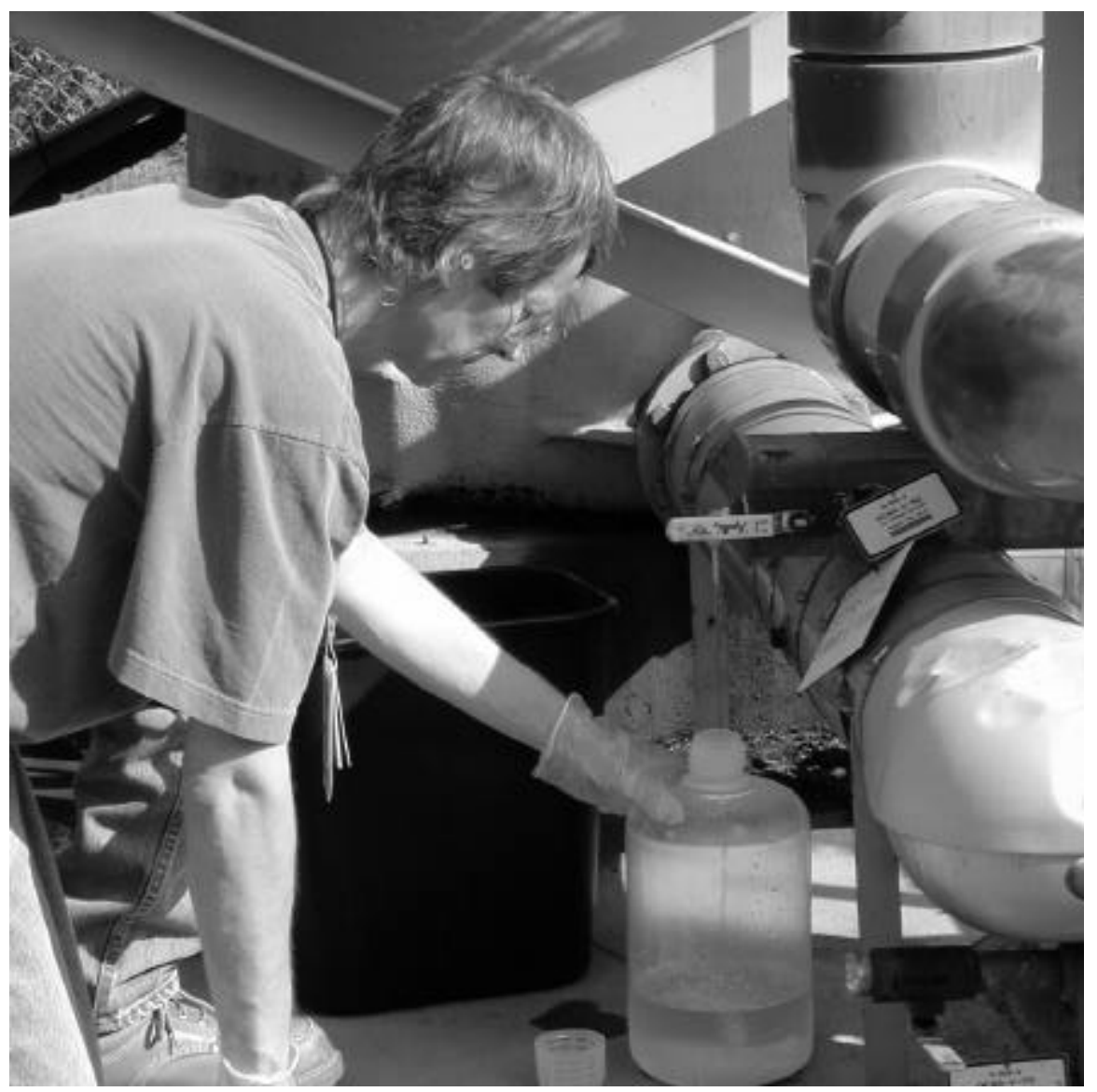

Figure 6: SRTC researcher Miles Denham collects large volume sample for a kinetic study of mercury-tin reaction rates. 


\section{Results}

The mercury treatment was extremely efficient as documented by the dose-response studies. The dose response results for both project stages are shown in Figure 7 . In the undosed samples, the treatment removed $0 \%$ ( \pm approximately $15 \%)$. Removal in the treated samples varied by dose. Low doses $(<0.0001 \mathrm{mg} / \mathrm{L}$ stannous chloride dihydrate $)$ showed little removal. Stannous chloride dihydrate reagent doses above $0.01 \mathrm{mg} / \mathrm{L}$ showed relatively complete removal $(>94 \%)$ - the residual total mercury in all of these samples was reduced to levels below $10 \mathrm{ng} / \mathrm{L}$.

Stannous Chloride Mercury Treatment Results

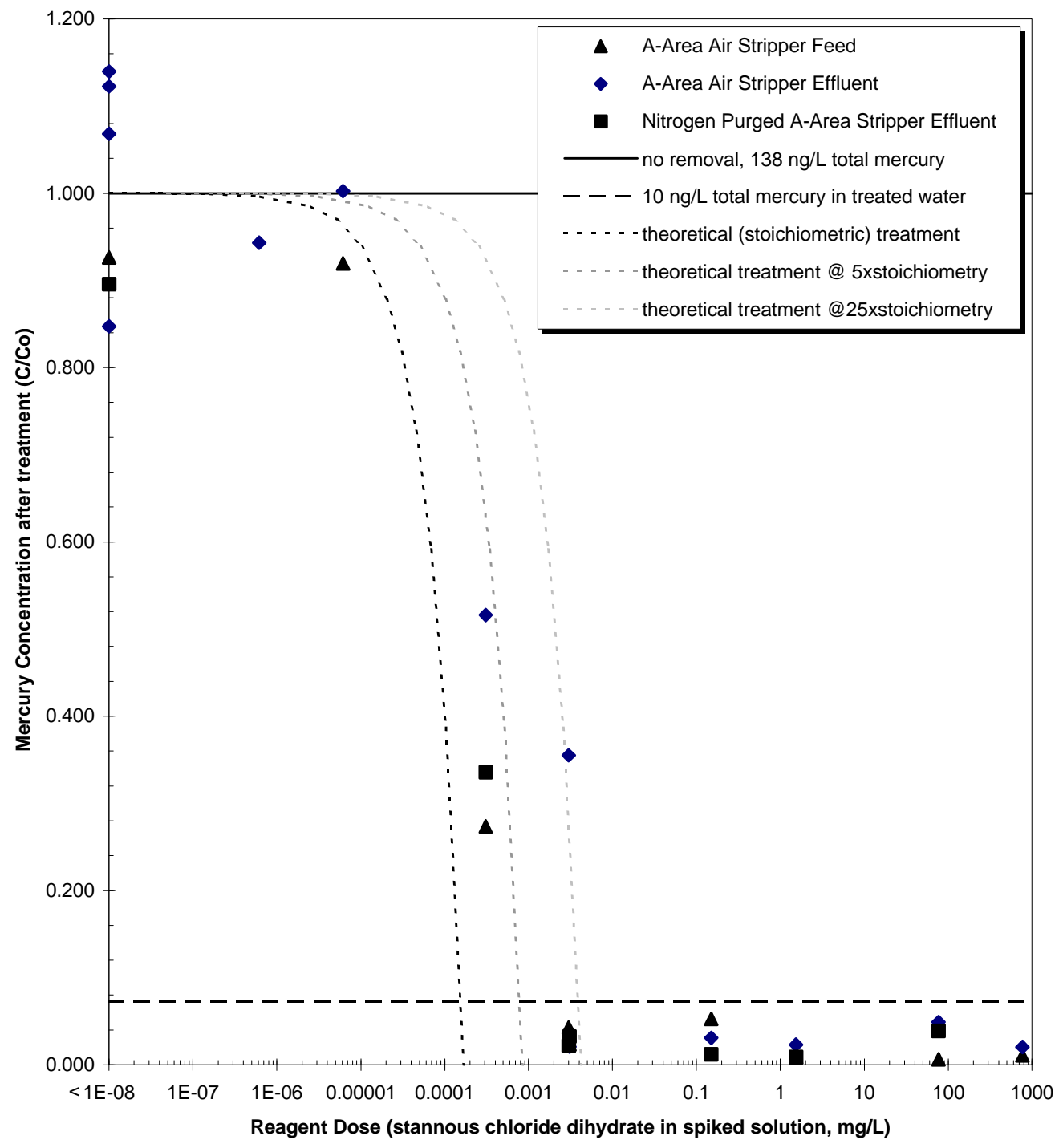

Figure 7: Mercury Treatment - Various Runs Performed at the A-Area Stripper at SRS 
Reagent doses between $0.0001 \mathrm{mg} / \mathrm{L}$ and $0.01 \mathrm{mg} / \mathrm{L}$ responded in a regular manner generally consistent with the stoichiometry of the redox reaction between $\mathrm{Hg}$ (II) and $\mathrm{Sn}(\mathrm{II})$. The curved lines on Figure 7 are calculations indicating expected performance based on $1 x, 5 x$ and $25 x$ the theoretical stoichiometry. With only one exception, the data in this critical reagent dose range fell between $1 \mathrm{x}$ to $5 \mathrm{x}$ the theoretical optimum performance. This suggests that the desired reaction is favored and that the process is viable for the tested environmental conditions. Competing reactions (e.g., with the organic contaminants in the stripper feed water and/or dissolved oxygen in the stripper feed water and the stripper effluent) are not adversely scavanging the reagent, despite the presence of competing molecules in solution at levels that are several orders of magnitude higher than the target $\mathrm{Hg}(\mathrm{II})$. Notably, the dose-response in one sample fell between $5 x$ and $25 x$ the theoretical stoichiometry. Because of the upstream treatment in an air stripper, this "effluent" sample was relatively high in dissolved oxygen (approximately $10 \mathrm{mg} / \mathrm{L}$ dissolved oxygen versus the stripper feedwater at about $3 \mathrm{mg} / \mathrm{L}$ ). This single data point may indicate a detectable influence of high (saturated) dissolved oxygen on treatment efficiency. A replicate of this sample, however, showed effective mercury removal to $<10 \mathrm{ng} / \mathrm{L}$. Based on the results, a target dose range of $5 \mathrm{x}$ to $25 \mathrm{x}$ stoichiometry would be a reasonable design basis for treatment of waters similar to those tested.

The kinetic study indicated that addition of $\mathrm{Sn}$ (II) results in extremely rapid reduction of $\mathrm{Hg}(\mathrm{II})$ to $\mathrm{Hg}(0)$. For all of the $\mathrm{Sn}$ (II) addition experiments, the mercury evasion rate appears to be controlled by the purging process rather than the reaction rate. In the three experiments conducted at $22.8^{\circ} \mathrm{C}$., the mean removal rate ranged from about 27 to $29 \%$ of the $\mathrm{Hg}$ present per volume of purge gas (i.e., for each $500 \mathrm{~mL}$ of purge gas representing a 1:1 air:water ratio). For the single experiment at $0^{\circ} \mathrm{C}$., the mean removal rate fell to about $19 \%$ of the $\mathrm{Hg}$ present per volume of purge gas. In both deionized water and in groundwater, virtually no mercury was evaded without the addition of $\mathrm{Sn}(\mathrm{II})$. These conclusions are clearly documented in Figure 8. This figure plots the laboratory data along with lines showing theoretical performance. The theoretical lines have not been fitted to the data and are based solely on purge efficiency calculated from literature values of solubility and vapor pressure of elemental mercury (Table 3).

For these relatively simple conditions, the literature values of vapor pressure and solubility can be combined into a “dimensionless" Henry's Law constant (H'):

$$
\mathrm{H}^{\prime}=\frac{\text { (vapor pressure in units of } \mathrm{mg} \mathrm{Hg} \text { per L of air) }}{\text { (solubility in units of } \mathrm{mg} \mathrm{Hg} \text { per L of water) }}
$$


Based on mass balance and integration over time, the purge efficiency can then be approximated as a function of $\mathrm{H}^{\prime}$ and the ratio of air volume purged to water volume in $\operatorname{vessel}\left(\eta^{\prime}\right)$ :

$$
\mathrm{Hg}_{(\eta)^{\prime}} / \mathrm{Hg}_{(0)}=\mathrm{e}^{-\left(\mathrm{H}^{\prime} \eta^{\prime}\right)}
$$

Normalized removal rates calculated using this equation correspond well with the those reported from the raw data $\left(29 \%\right.$ of he $\mathrm{Hg}$ present per volume of purge gas at $22.8^{\circ} \mathrm{C}$. and $16 \%$ of the $\mathrm{Hg}$ present per volume of purge gas at $0^{\circ} \mathrm{C}$ ). The theoretical lines in Figure 8, based solely on expected sparge rate, provide a reasonable match the measured data. This suggests that sparging controlled the mercury removal rate in the experiments and that the reaction kinetics $(\mathrm{Hg}(\mathrm{II}) \Rightarrow \mathrm{Hg}(0))$ are relatively fast.

Table 3. Literature values of solubility and vapor pressure used to calculate Henry's Law and theoretical sparge performance

\begin{tabular}{|c|c|c|c|}
\hline \hline Temperature $\left({ }^{\circ} \mathrm{C}\right)$ & $\begin{array}{c}\text { vapor pressure } \\
\text { (mg Hg / L air) }\end{array}$ & $\begin{array}{c}\text { solubility } \\
(\mathrm{mg} \mathrm{Hg} / \mathrm{L} \text { water })\end{array}$ & $\begin{array}{c}\text { H' } \\
\text { (“dimensionless” } \\
\text { Henry's Law } \\
\text { Constant) }\end{array}$ \\
\hline 0 & 0.0027 & 0.015 & 0.18 \\
\hline 22.8 & 0.018 & 0.053 & 0.34 \\
\hline
\end{tabular}

Chemistry data interpolated from Sanamesa, 1975. See also Clever, 1987. 
Kinetic Experiment

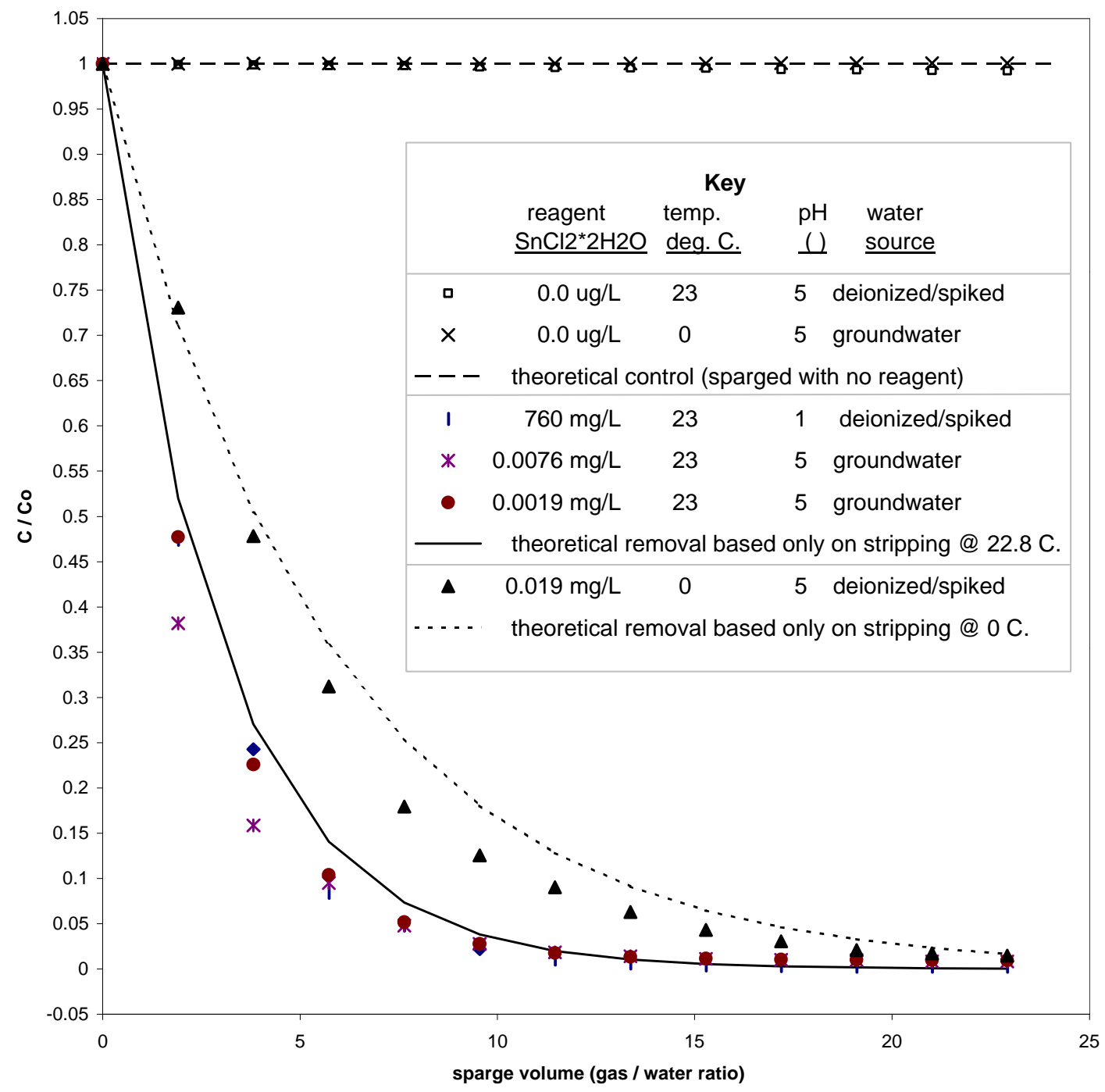

Figure 8: Results of Kinetic Study 


\section{Engineering Considerations}

Two key engineering considerations were preliminarily evaluated during Stage 2 of the project. These were: 1) equipment materials selection and compatibility, and 2) alternative stannous chloride delivery options.

All of the materials in a full scale system (including storage vessels, and downstream fittings, seals, tubing, valves, flow meters, check valves, and the like) need to be compatible with the stannous chloride reagent. Table 4 presents a list of potentially acceptable and unacceptable construction materials. Several commonly available materials were identified as "excellent" in standard 48 hour compatibility tests - 316 stainless steel, bronze, teflon (PTFE®), various elastomers, and many other materials. These represent first choices in future designs. Confirmation that selected materials will perform over an extended period of time is recommended to support long-term operation.

Two basic options are available for delivery of the stannous chloride solution to a process. The simplest is a pressure infusion system that uses an inert gas to force the solution into the process water. In this system, the operator modulates the flow using a high precision needle valve (or other flow controller). The reagent solution is maintained under a blanket of inert gas. The advantages of this system are its simplicity and elegance. The disadvantages of this system are the requirement to place the entire volume of stored reagent under moderate pressures (circa 50 to $100 \mathrm{psig}$ ) and potential operational problems associated with the needle valve / flow controller. These issues would require appropriate engineering-design responses. For example, assuring proper certification and pressure protection for the reagent tank, as well as documenting that the flow controller would operate reliably and robustly under field conditions (especially in the case where small amounts of particulates - oxidized stannous chloride precipitate may be passing through the system).

The second stannous chloride delivery approach, uses a high-precision positivedisplacement infusion pump to deliver the reagent into the process water. In this system, the operator adjusts the delivery using the pump controls and confirms the flow using a monitoring system. The advantages of this system relative to pressure infusion include: reduction of pressure needed in reagent storage reservoir, more robust to the presence of small quantities of stannous chloride precipitate, and process control compatible and easily integrated with most common systems. Disadvantages include: higher initial cost, and the need to properly maintain the pump. It is important to note that in the pump system, the reagent would still need to be blanketed with inert gas (but the pressure could be set to levels far below those that would require code certification (e.g., 2 psig versus $15 \mathrm{psig})$ ). The disadvantages could be minimized / mitigated by careful selection of a high quality pump that is designed for continuous-duty high-precision low-flow infusion in an industrial setting. Many such pumps are available.

Initial prototypes of both a pressure infusion and a pump system were assembled during Stage 2. The prototypes, sized for a $200 \mathrm{gpm}$ water treatment plant, were constructed of 
WSRC-RP-2000-01028

Rev. 0

Page 19 of 38

materials rated as excellent - notably 316 stainless steel for the storage container, tubing and pump head, glass for the flow meter tube, and PFTE or viton for seals. Preliminary evaluation of the systems suggests that successful full-scale implementation is probable. Additional long-term testing of reagent stability and operational robustness is recommended.

Table 4. Compatibility data for materials in contact with high concentration stannous chloride solutions

\begin{tabular}{|c|c|c|c|c|}
\hline $\begin{array}{l}\text { Materials with } \\
\text { EXCELLENT } \\
\text { Compatibility } \\
\text { (footnotes) }\end{array}$ & $\begin{array}{l}\text { Materials with } \\
\text { GOOD } \\
\text { Compatibility } \\
\text { (footnotes) }\end{array}$ & $\begin{array}{l}\text { Materials with } \\
\text { FAIR } \\
\text { Compatibility } \\
\text { (footnotes) }\end{array}$ & $\begin{array}{l}\text { Materials with } \\
\text { POOR } \\
\text { Compatibility } \\
\text { (footnotes) }\end{array}$ & $\begin{array}{l}\text { Some materials } \\
\text { with } \\
\text { no tabulated data } \\
\text { on compatibility }\end{array}$ \\
\hline 316 ss (2) & Hastelloy-C® & 304 ss (2) & Aluminum & ABS plastic \\
\hline Bronze (1) & LDPE (2) & EPDM & Carpenter 20 & Acetal - Delrin ${ }^{\circledR}$ \\
\hline Buna N - Nitrile & Silicone & Hytrel $\AA$ & & Brass \\
\hline Ceramic $-\mathrm{Al}_{2} \mathrm{O}_{3}$ & & Nylon (1) & & Carbon-graphite \\
\hline CPVC (2) & & & & Cast iron \\
\hline Epoxy & & & & Ceramic magnet \\
\hline Glass & & & & Copper \\
\hline Hypalon ${ }^{\circledR}(1)$ & & & & FEP - teflon ${ }^{\circledR}$ \\
\hline Kel-F® & & & & PFA -- teflon ${ }^{\circledR}$ \\
\hline Natural rubber & & & & polycarbonate \\
\hline Neoprene (1) & & & & \\
\hline NORYL® (2) & & & & \\
\hline Polypropylene & & & & \\
\hline PPS - Ryton ${ }^{\circledR}(1)$ & & & & \\
\hline PFTE - teflon ${ }^{\circledR}$ & & & & \\
\hline PVC (1) & & & & \\
\hline PVDF - Kynar® & & & & \\
\hline Titanium & & & & \\
\hline Tygon $\AA$ & & & & \\
\hline Viton $®$ & & & & \\
\hline
\end{tabular}

Compatibility Terminology Definitions:

Excellent $=$ No observable effects during standard $(48 \mathrm{hr})$ testing procedures under listed conditions

Good $=$ Minor effects observed (such as discoloration or slight corrosion)

Fair $=$ Moderate effect observed (such as softening, loss of strength, or swelling), not recommended for continuous use.

Poor - Severe effects, not recommended for any use

Footnotes:

$(1)=$ Meets listed performance up to $72^{\circ} \mathrm{F}$. $\left(22^{\circ} \mathrm{C}\right.$. $)$

(2) $=$ Meets listed performance up to $120^{\circ} \mathrm{F}$. $\left(48^{\circ} \mathrm{C}\right.$. $)$

Data from public sources such as Cole Parmer, New Age Industries, Good Year, etc. 
WSRC-RP-2000-01028

Rev. 0

Page 20 of 38

\section{Scoping Analysis}

The data indicate that chemical reduction combined with sparging/stripping is a viable mercury treatment for waters containing $\mathrm{Hg}(\mathrm{II})$. A scoping calculation for a scenario similar to the A-Area Stripper illustrates the nature of a potential implementation. Specific assumptions for the scenario are the following:

- dose rate of $0.01 \mathrm{mg} / \mathrm{L}$ stannous chloride dihydrate (approximately $3 \mathrm{x}$ the lowest tested dose in this study) will provide effective-continuous-robust mercury removal, and

- water flow of $0.8 \mathrm{~m}^{3} / \mathrm{min}$ (approx. $200 \mathrm{gpm}$ ) to be treated containing $150 \mathrm{ng} / \mathrm{L}$ total mercury as $\mathrm{Hg}(\mathrm{II})$

For this case, realistic design, capital and installation costs for a good quality dosing system are $<\$ 50,000$. Approximately $5 \mathrm{Kg}$ of reagent are needed to treat an entire year of flow. In such a quantity, reagent grade stannous chloride dihydrate costs approximately $\$ 150 / \mathrm{Kg}$ for a yearly reagent cost of less than $\$ 1000$. Dosing would need to be performed from a high concentration reagent reservoir using a high precision pump or pressure infusion system. The reservoir requires a nitrogen (or inert gas) headspace for reagent stability. All construction materials up to the infusion point need to be compatible with high concentration stannous chloride solutions. Logistics appear reasonable for either dosing option. Reagent can be mixed at $60,000 \mathrm{mg} / \mathrm{L}$ in batches of $20 \mathrm{~L}$ and infused at a rate of approximately $0.15 \mathrm{~mL} / \mathrm{min}$. Each batch would last three months (i.e., operators would need to prepare reagent only 4 times per year). Reagent preparation, combined with maintaining logs, periodic adjustments and repairs, should represent less than 0.2 FTE (approximately $\$ 40,000 /$ year). If costs for reagents were approximately $\$ 800$ (as described above) and replacement parts and other supplies was $\$ 5000$, annual operational costs would be $\$ 46,000$. This represents an operating cost of about $\$ 0.11 / \mathrm{m}^{3}(<\$ 0.5$ per 1000 gallons). These costs assume that an air stripper is in place (such as the case of treating the feed water to the A-Area Stripper). Air stripping/sparging costs on the order of $\$ 250,000$ (capital), with operations typically costing $\$ 0.2 / \mathrm{m}^{3}$ (<\$1 per 1000 gallons). Thus, a complete $200 \mathrm{gpm}$ system would have approximate costs of $\$ 300,000$ and an operating cost of $<\$ 0.3 / \mathrm{m}^{3}(<\$ 1.50$ per 1000 gallons). This cost, conservatively calculated, is significantly less than traditional metals treatment technology costs - especially for target treatment concentrations below 10 $\mathrm{ng} / \mathrm{L}$. 


\section{References}

Clever, H. L., 1987. Solubility Series, Volume 29: Mercury in Liquids, Compressed Gases, Molten Salts and Other Elements. Pergamon Press, Oxford England.

Denham, M., B. Looney, J. Koch II, D. Jackson, W. Fulmer, R. Roseberry, J. Noonkester, 1999. SRS Background Mercury Study: Preliminary Summary of Ultra-Low Level Analytical Data, SRT-EST-99-0322, Westinghouse Savannah River Company, Aiken SC 29808.

Looney, B. B., 2000. Laboratory Notebook: Ultralow Level Mercury Treatment Using Chemical Reduction and Air Stripping, WSRC-NB-2000-00028, Westinghouse Savannah River Company, Aiken SC 29808.

Sanemasa, I., 1975. Bulletin Chemical Society of Japan, 48:1795-1798.

Southworth, G., 1996. "Outfall 51 Treatment System”, in Mercury Abatement Report on the U. S. Department of Energy's Oak Ridge Y-12 Plant for the Fiscal Year 1996. Y/ER277. Oak Ridge Y-12 Plant, Oak Ridge TN 37831, pp 2-2 and 2-3.

Vangelas, K. M. (2000). Task Technical Plan for Ultralow Level Mercury Treatment Using Chemical Reduction and Air Stripping, WSRC-TR-2000-00040, Westinghouse Savannah River Company, Aiken SC 29808. 
WSRC-RP-2000-01028

Rev. 0

Page 22 of 38 
WSRC-RP-2000-01028

Rev. 0

Page 23 of 38

\section{APPENDIX A - DOSE RESPONSE STUDY DATA}


WSRC-RP-2000-01028

Rev. 0

Page 24 of 38

\section{SUMMARY DOSE VS. MERCURY DATA FOR FIELD EXPERIMENT}

Stage 1 Dose Response Results:

\begin{tabular}{|c|c|c|c|c|c|}
\hline Sample No. & $\begin{array}{l}0 \\
\frac{1}{\pi} \\
\frac{2}{6}\end{array}$ & $\begin{array}{c}\text { Dose } \\
\text { Protocol }\end{array}$ & $\begin{array}{c}\text { Dose of } \\
\text { stannous } \\
\text { chloride } \\
\text { dihydrate } \\
(\mathrm{mg} / \mathrm{L})\end{array}$ & $\begin{array}{c}\text { Final } \mathrm{Hg} \\
(\mathrm{ng} / \mathrm{L})\end{array}$ & $\mathrm{C} / \mathrm{CO}$ \\
\hline & & & & & \\
\hline SRDHG 01 & -- & 0 & 0 & 146.9 & 1.417 \\
\hline SRDHG 02 & -- & 0 & 0 & 116.5 & 1.124 \\
\hline SRDHG 03 & -- & $1 \mathrm{ml} \mathrm{A}$ & 766 & 2.83 & 0.027 \\
\hline SRDHG 04 & -- & $0.1 \mathrm{ml} \mathrm{A}$ & 76.6 & 6.72 & 0.065 \\
\hline SRDHG 05 & -- & $1 \mathrm{ml} \mathrm{B}$ & 1.54 & 3.18 & 0.031 \\
\hline SRDHG 06 & -- & $0.1 \mathrm{ml} \mathrm{B}$ & 0.15 & 4.26 & 0.041 \\
\hline SRDHG 07 & -- & $1 \mathrm{ml} \mathrm{C}$ & 0.003 & 48.83 & 0.471 \\
\hline & & & & & \\
\hline & & & & & \\
\hline SRDHG 10 & --- & 0 & 0 & 127.4 & 1.229 \\
\hline SRDHG 13 & -- & $1 \mathrm{ml} \mathrm{A}$ & 766 & 1.47 & 0.014 \\
\hline SRDHG 14 & -- & $0.1 \mathrm{ml} \mathrm{A}$ & 76.6 & 0.89 & 0.009 \\
\hline SRDHG 15 & -- & $1 \mathrm{ml} \mathrm{B}$ & 1.54 & 1.16 & 0.011 \\
\hline SRDHG 16 & -- & $0.1 \mathrm{ml} \mathrm{B}$ & 0.15 & 7.24 & 0.070 \\
\hline SRDHG 17 & -- & $1 \mathrm{mlC}$ & 0.003 & 5.92 & 0.057 \\
\hline SRDHG 8 & N2 & $1 \mathrm{ml} \mathrm{C}$ & 0.003 & 3.03 & 0.029 \\
\hline SRDHG 9 & N2 & $0.1 \mathrm{ml} \mathrm{B}$ & 0.15 & 1.67 & 0.016 \\
\hline SRDHG 11 & N2 & $1 \mathrm{ml} \mathrm{B}$ & 1.54 & 1.24 & 0.012 \\
\hline SRDHG 12 & N2 & $0.1 \mathrm{ml} \mathrm{A}$ & 76.6 & 5.35 & 0.052 \\
\hline & & & & & \\
\hline & & & & & \\
\hline average Co & & & & 103.6517 & \\
\hline
\end{tabular}

Stage 2 Dose Response Results:

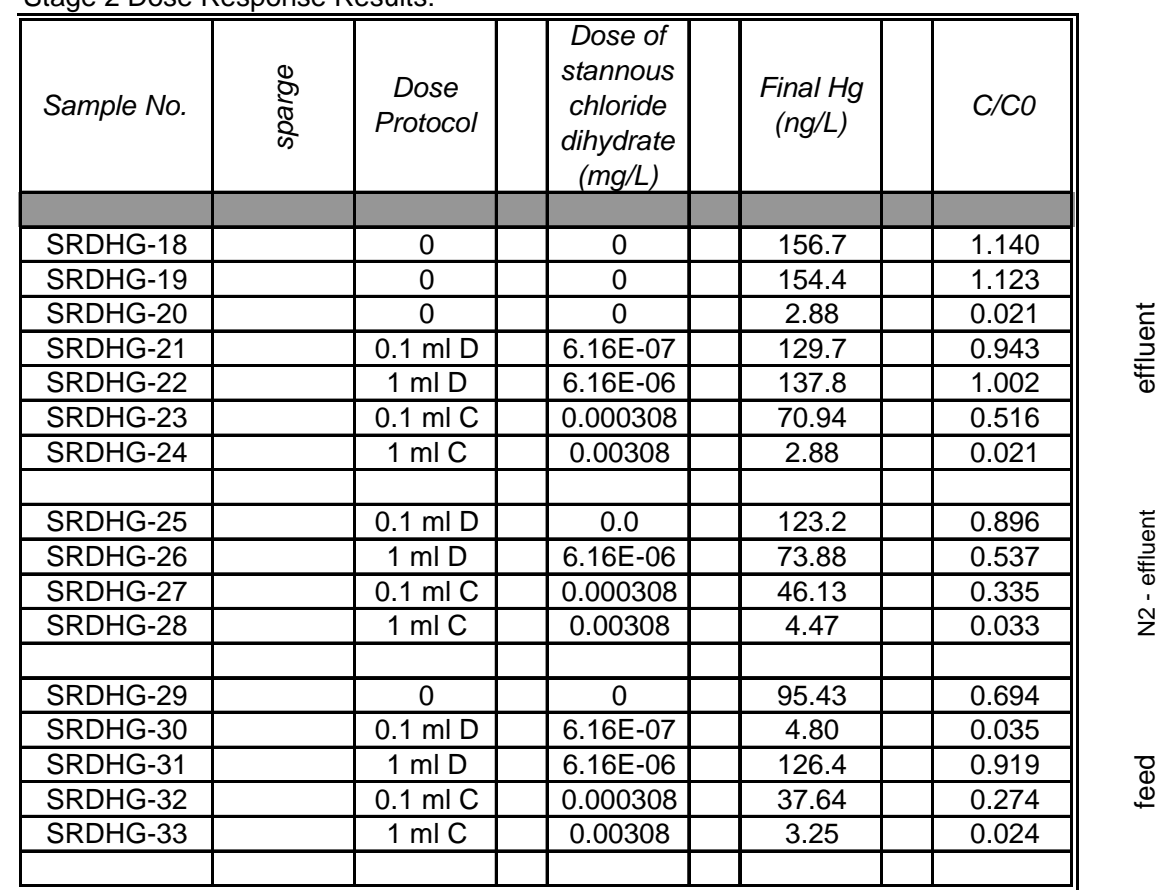


WSRC-RP-2000-01028

Rev. 0

Page 25 of 38

RAW DATA FROM STAGE 1 FIELD EXPERIMENT

\begin{tabular}{|c|c|c|c|c|c|}
\hline \multicolumn{6}{|c|}{ Total Mercury in Water Samples (Westinghouse } \\
\hline \multicolumn{6}{|c|}{ analyzed by } \\
\hline \multicolumn{6}{|c|}{ Frontier Geosciences Inc. 414 Pontius North, Suite B Seattle WA 98109} \\
\hline \multicolumn{6}{|c|}{ phone: 206-622-6960 fax: 206-622-6870 e-mail: nicolasb@frontier.wa.com } \\
\hline & bottle & collection & analysis & & \\
\hline sample ID & number & date & date & {$[\mathrm{Hg}], \mathbf{n g} / \mathrm{L}$} & comment \\
\hline SRDHG-01 & glass & $6 / 21 / 00$ & $6 / 23 / 00$ & 146.90 & \\
\hline SRDHG-02 & glass & $6 / 21 / 00$ & $6 / 23 / 00$ & 116.5 & \\
\hline SRDHG-03 & glass & $6 / 21 / 00$ & $6 / 23 / 00$ & 2.83 & \\
\hline SRDHG-04 & glass & $6 / 21 / 00$ & $6 / 23 / 00$ & 6.72 & \\
\hline SRDHG-05 & glass & $6 / 21 / 00$ & $6 / 23 / 00$ & 3.18 & \\
\hline SRDHG-06 & glass & $6 / 21 / 00$ & $6 / 23 / 00$ & 4.26 & QA Sample \\
\hline SRDHG-07 & glass & $6 / 21 / 00$ & $6 / 23 / 00$ & 48.83 & \\
\hline SRDHG-08 & glass & $6 / 21 / 00$ & $6 / 23 / 00$ & 3.03 & \\
\hline SRDHG-09 & glass & $6 / 21 / 00$ & $6 / 23 / 00$ & 1.67 & \\
\hline SRDHG-10 & glass & $6 / 21 / 00$ & $6 / 23 / 00$ & 127.40 & \\
\hline SRDHG-11 & glass & $6 / 21 / 00$ & $6 / 23 / 00$ & 1.24 & \\
\hline SRDHG-12 & glass & $6 / 21 / 00$ & $6 / 23 / 00$ & 5.35 & \\
\hline SRDHG-13 & glass & $6 / 21 / 00$ & $6 / 23 / 00$ & 1.47 & \\
\hline SRDHG-14 & glass & $6 / 21 / 00$ & $6 / 23 / 00$ & 0.89 & \\
\hline SRDHG-15 & glass & $6 / 21 / 00$ & $6 / 23 / 00$ & 1.16 & \\
\hline SRDHG-16 & glass & $6 / 21 / 00$ & $6 / 23 / 00$ & 7.24 & \\
\hline \multirow[t]{2}{*}{ SRDHG-17 } & glass & $6 / 21 / 00$ & $6 / 23 / 00$ & 5.92 & \\
\hline & & & & & \\
\hline blank-1 & & & $6 / 2$ & 012 & \\
\hline $\begin{array}{l}\text { blank-1 } \\
\text { blank-2 }\end{array}$ & & & $\frac{6 / 23 / 00}{6 / 23 / 00}$ & 0.1 & \\
\hline blank-3 & & & $6 / 23 / 00$ & 0.13 & \\
\hline mean & & & & 0.12 & \\
\hline \multirow[t]{3}{*}{ SD } & & & & 0.02 & estimated MDL $=0.04 \mathrm{ng} / \mathrm{L}$ \\
\hline & & & & & \\
\hline & & & & & \\
\hline \multicolumn{6}{|l|}{ repeatability } \\
\hline SRDHG-06 rep 1 & glass & $6 / 21 / 00$ & $6 / 23 / 00$ & 4.45 & \\
\hline SRDHG-06 rep 2 & glass & $6 / 21 / 00$ & $6 / 23 / 00$ & 4.07 & \\
\hline mean & & & & 4.26 & $8.5 \%$ RPD \\
\hline \multirow{2}{*}{\multicolumn{6}{|c|}{ standard addition }} \\
\hline & & & & & \\
\hline SRDHG-06 + $20.20 \mathrm{ng} / \mathrm{L} \mathrm{MS}$ & glass & $6 / 21 / 00$ & $6 / 23 / 00$ & 23.29 & $94.2 \%$ recovery \\
\hline SRDHG-06 + $20.20 \mathrm{ng} / \mathrm{L} \mathrm{MSD}$ & glass & $6 / 21 / 00$ & $6 / 23 / 00$ & 23.38 & $94.7 \%$ recovery \\
\hline \multirow[t]{3}{*}{ mean } & & & & 23.34 & $0.3 \% \mathrm{RPD}$ \\
\hline & & & & & \\
\hline & & & & & \\
\hline \multicolumn{6}{|l|}{ certified standard } \\
\hline NIST-1641-d & & & $6 / 23 / 00$ & 7,663 & $96.4 \%$ recovery \\
\hline certified value & & & & 7,950 & \\
\hline
\end{tabular}


WSRC-RP-2000-01028

Rev. 0

Page 26 of 38

BLANKS PERFORMED ON EVERY CLEANED PURGE VESSEL

\begin{tabular}{|c|c|c|c|c|c|}
\hline \multicolumn{6}{|c|}{ Total Mercury in Purge Vessel Blanks (West } \\
\hline \multicolumn{6}{|c|}{ analyzed by } \\
\hline \multicolumn{6}{|c|}{ Frontier Geosciences Inc. 414 Pontius North, Suite B Seattle WA 98109} \\
\hline \multicolumn{6}{|c|}{ phone: 206-622-6960 fax: 206-622-6870 e-mail: nicolasb@frontier.wa.com } \\
\hline sample ID & $\begin{array}{c}\text { bottle } \\
\text { number }\end{array}$ & $\begin{array}{c}\text { collection } \\
\text { date }\end{array}$ & $\begin{array}{c}\text { analysis } \\
\text { date }\end{array}$ & {$[\mathrm{Hg}], \mathbf{n g} / \mathbf{L}$} & comment \\
\hline field purge vessel blank test \#1 & glass & $\mathrm{n} / \mathrm{a}$ & $3 / 9 / 00$ & 0.30 & \\
\hline field purge vessel blank test \#2 & glass & $\mathrm{n} / \mathrm{a}$ & $3 / 9 / 00$ & 0.35 & \\
\hline field purge vessel blank test \#3 & glass & $\mathrm{n} / \mathrm{a}$ & $3 / 9 / 00$ & 0.27 & \\
\hline field purge vessel blank test \#4 & glass & $\mathrm{n} / \mathrm{a}$ & $3 / 9 / 00$ & 0.26 & \\
\hline field purge vessel blank test \#5 & glass & $\mathrm{n} / \mathrm{a}$ & $3 / 9 / 00$ & 0.29 & \\
\hline field purge vessel blank test \#6 & glass & $\mathrm{n} / \mathrm{a}$ & $3 / 9 / 00$ & 0.17 & \\
\hline field purge vessel blank test \#7 & glass & $\mathrm{n} / \mathrm{a}$ & $3 / 9 / 00$ & 0.47 & \\
\hline field purge vessel blank test \#8 & glass & $\mathrm{n} / \mathrm{a}$ & $3 / 9 / 00$ & 0.27 & \\
\hline field purge vessel blank test \#9 & glass & $\mathrm{n} / \mathrm{a}$ & $3 / 9 / 00$ & 0.35 & \\
\hline field purge vessel blank test \#10 & glass & $\mathrm{n} / \mathrm{a}$ & $3 / 9 / 00$ & 0.73 & \\
\hline field purge vessel blank test \#11 & glass & $\mathrm{n} / \mathrm{a}$ & $3 / 9 / 00$ & 0.19 & \\
\hline field purge vessel blank test \#12 & glass & $\mathrm{n} / \mathrm{a}$ & $3 / 9 / 00$ & 0.40 & \\
\hline field purge vessel blank test \#13 & glass & $\mathrm{n} / \mathrm{a}$ & $3 / 9 / 00$ & 0.28 & mean: $0.33 \mathrm{ng} / \mathrm{L}$ \\
\hline field purge vessel blank test \#14 & glass & $\mathrm{n} / \mathrm{a}$ & $3 / 9 / 00$ & 0.36 & SD: $0.14 \mathrm{ng} / \mathrm{L}$ \\
\hline field purge vessel blank test \#15 & glass & $\mathrm{n} / \mathrm{a}$ & $3 / 9 / 00$ & 0.16 & $\mathrm{~N}: 16$ \\
\hline field purge vessel blank test \#16 & glass & $\mathrm{n} / \mathrm{a}$ & $3 / 9 / 00$ & 0.43 & \\
\hline blank-1 & & & $3 / 9 / 00$ & 0.08 & \\
\hline blank-2 & & & $3 / 9 / 00$ & 0.05 & \\
\hline blank-3 & & & $3 / 9 / 00$ & 0.1 & \\
\hline mean & & & & 0.08 & \\
\hline SD & & & & 0.03 & estimated MDL $=0.08 \mathrm{ng} / \mathrm{L}$ \\
\hline NIST-1641-d rep 1 & & & $3 / 9 / 00$ & 7,801 & $98.1 \%$ recovery \\
\hline NIST-1641-d rep 2 & & & $3 / 9 / 00$ & 7,728 & $97.2 \%$ recovery \\
\hline certified value & & & & 7,950 & $0.9 \%$ RSD \\
\hline
\end{tabular}


WSRC-RP-2000-01028

Rev. 0

Page 27 of 38

RAW DATA FROM STAGE 2 FIELD EXPERIMENT

\begin{tabular}{|c|c|c|c|c|c|}
\hline \multirow{2}{*}{\multicolumn{6}{|c|}{$\frac{\text { Total Mercury in Water Samples (Westing }}{\text { analyzed by }}$}} \\
\hline & & & & & \\
\hline \multicolumn{6}{|c|}{ Frontier Geosciences Inc. 414 Pontius North, Suite B Seattle WA 98109} \\
\hline \multicolumn{6}{|c|}{ phone: 206-622-6960 fax: 206-622-6870 e-mail: nicolasb@frontier.wa.com } \\
\hline & bottle & collection & analysis & & \\
\hline sample ID & number & date & date & {$[\mathrm{Hg}], \mathrm{ng} / \mathrm{L}$} & comment \\
\hline SRDHG-18 & FGSB-547 & 7-Aug-00 & 9-Aug-00 & 156.7 & \\
\hline SRDHG-19 & FGSB-384 & 7-Aug-00 & 9-Aug-00 & 154.4 & \\
\hline SRDHG-20 & glass & 7-Aug-00 & 9-Aug-00 & 2.88 & \\
\hline SRDHG-21 & glass & 7-Aug-00 & 9-Aug-00 & 129.7 & \\
\hline SRDHG-22 & glass & 7-Aug-00 & 9-Aug-00 & 137.8 & \\
\hline SRDHG-23 & glass & 7-Aug-00 & 9-Aug-00 & 70.94 & \\
\hline SRDHG-24 & glass & 7-Aug-00 & 9-Aug-00 & 2.88 & \\
\hline SRDHG-25 & glass & 7-Aug-00 & 9-Aug-00 & 123.2 & \\
\hline SRDHG-26 & glass & 7-Aug-00 & 9-Aug-00 & 73.88 & \\
\hline SRDHG-27 & glass & 7-Aug-00 & 9-Aug-00 & 46.13 & \\
\hline SRDHG-28 & FGSB-202 & 7-Aug-00 & 9-Aug-00 & 4.47 & \\
\hline SRDHG-29 & SK10-27 & 7-Aug-00 & 9-Aug-00 & 95.43 & \\
\hline SRDHG-30 & CMC-319 & 7-Aug-00 & 9-Aug-00 & 4.80 & QC Sample \\
\hline SRDHG-31 & FGSB-002 & 7-Aug-00 & 9-Aug-00 & 126.4 & \\
\hline SRDHG-32 & TSI-8 & 7-Aug-00 & 9-Aug-00 & 37.64 & \\
\hline SRDHG-33 & FGSB-929 & 7-Aug-00 & 9-Aug-00 & 3.25 & \\
\hline blank-1 & & & $9-A u q-00$ & 0.05 & \\
\hline blank-2 & & & 9-Aug-00 & 0.07 & \\
\hline blank-3 & & & 9-Aug-00 & 0.07 & \\
\hline mean & & & & 0.06 & \\
\hline SD & & & & 0.01 & estimated $\mathrm{MDL}=0.03 \mathrm{ng} / \mathrm{L}$ \\
\hline blank spike @ 5.00 ng/L rep 1 & & & 9-Aug-00 & 4.77 & $95.4 \%$ recovery \\
\hline blank spike @ 5.00 ng/L rep 2 & & & 9-Aug-00 & 5.19 & $103.8 \%$ recovery \\
\hline mean & & & & 4.98 & $8.4 \%$ RPD \\
\hline SRDHG-30 rep 1 & CMC-319 & 7-Aug-00 & 9-Aug-00 & 5.16 & \\
\hline SRDHG-30 rep 2 & CMC-319 & 7-Aug-00 & 9-Aug-00 & 4.44 & \\
\hline mean & & & & 4.80 & $15.0 \%$ RPD \\
\hline SRDHG-30 + $20.20 \mathrm{ng} / \mathrm{L} \mathrm{MS}$ & CMC-319 & 7-Auq-00 & 9-Auq-00 & 23.60 & $93.1 \%$ recovery \\
\hline SRDHG-30 + $20.20 \mathrm{ng} / \mathrm{L} \mathrm{MSD}$ & CMC-319 & 7-Aug-00 & 9-Aug-00 & 24.58 & $97.9 \%$ recovery \\
\hline mean & & & & 24.09 & $4.1 \%$ RPD \\
\hline NIST-1641-d (200:1 dilution) & & & 9-Aug-00 & 7,327 & $92.2 \%$ recovery \\
\hline certified value & & & & 7,950 & at 200:1 dilution \\
\hline & & & & & \\
\hline
\end{tabular}


WSRC-RP-2000-01028

Rev. 0

Page 28 of 38 
WSRC-RP-2000-01028

Rev. 0

Page 29 of 38

\section{APPENDIX B - KINETIC STUDY DATA}




\title{
Kinetics of $\mathrm{Hg}$ Volatilization form WSRC Well Water using $\mathrm{Sn}$ (II) as a reductant
}

\author{
Nicolas S Bloom \\ Frontier Geosciences Inc. \\ 414 Pontius North, Suite B \\ Seattle, WA 98109
}

August 16, 2000

\section{Objectives}

The objective of this project was to determine the rate of purging for $\mathrm{Hg}^{\circ}$ from aqueous solutions, after reduction with low stochiometric ratios of $\mathrm{Sn}$ (II). This work is in relation to the development of a method of treating $\mathrm{Hg}$ contaminated ground water by $\mathrm{SnCl}_{2}$ reduction and air stripping. Analysis was performed with standard (Level-2) QA/QC documentation, using EPA Method 1631 for total $\mathrm{Hg}$ and EPA draft method 1630 for methyl mercury.

\section{Sample Receipt}

1 five litre sample was received on August 8, 2000. The sample was received in good condition (although the cooler was at ambient temperature upon arrival) and was preserved by keeping $\operatorname{cool}\left(0^{\circ} \mathrm{C}\right)$ and dark, until the volatilization experiment could be conducted, 4 days later. The sample received is listed below:

\begin{tabular}{|c|c|c|c|c|}
\hline date rec. & bottle \# & location & analysis & comments \\
\hline $8 / 8 / 00$ & FGS-001 & 5-litre & kinetic expt. & cooler @ $8.8^{\circ} \mathrm{C}$ \\
\hline
\end{tabular}

\section{Experimental Methods}

Experimental Setup. Purging experiments were conducted from acid-cleaned $500 \mathrm{~mL}$ borosilicate glass gas-washing bottles. These bottles had a volume of 575 $\mathrm{mL}$, and were charged with $500 \mathrm{~mL}$ of aqueous sample for each experiment. The samples were purged with ultra-purified $\mathrm{N}_{2}$, at a flowrate of $220 \pm 20 \mathrm{~mL} / \mathrm{min}$, and $\mathrm{Hg}^{\circ}$ evaded collected onto freshly blanked gold coated quartz sand traps 
(the same traps as are used in EPA Method 1631). Taking into account the flowrate and the total volume of the purge vessels, the purge rate can also be expressed as 0.382 volumes $/ \mathrm{min}$. A total of six experiments were conducted, with the conditions as described in the table below.

\begin{tabular}{|c|c|c|c|c|c|}
\hline experiment & $\begin{array}{c}\text { sample } \\
\text { matrix }\end{array}$ & $\begin{array}{l}\text { [Hg] } \\
\mu \mathrm{g} / \mathrm{L}\end{array}$ & $\mathrm{T}^{\circ} \mathrm{C}$ & $\begin{array}{l}\operatorname{Sn}(\mathrm{II}) \\
\mu \mathrm{g} / \mathrm{L}\end{array}$ & pH \\
\hline$\# 1^{*}$ & DIW & 0.100 & 22.8 & 400,000 & 0.9 \\
\hline$\# 2$ & DIW & 0.100 & 0.0 & 0.0 & 5.0 \\
\hline$\# 3$ & well $\mathrm{H}_{2} \mathrm{O}$ & 0.138 & 22.8 & 10.0 & ambient \\
\hline$\# 4$ & well $\mathrm{H}_{2} \mathrm{O}$ & 0.138 & 22.8 & 0.0 & ambient \\
\hline$\# 5$ & well $\mathrm{H}_{2} \mathrm{O}$ & 0.138 & 22.8 & 4.0 & ambient \\
\hline$\# 6$ & well $\mathrm{H}_{2} \mathrm{O}$ & 0.138 & 22.8 & 1.0 & ambient \\
\hline
\end{tabular}

*same conditions as EPA M-1631

The samples were each purged for 60 minutes, with all of the evaded $\mathrm{Hg}^{\circ}$ being trapped by the use of sequential gold/sand traps. Because most of the $\mathrm{Hg}^{\circ}$ purges out over the first 5 minutes, an attempt was made to collect more traps over shorter intervals (15 seconds to 60 seconds per trap), and then longer intervals (5-10 minutes per trap) as the $\mathrm{Hg}^{\circ}$ levels in solution dropped. At the beginnings of the experiments with $\mathrm{SnCl}_{2}$, from 4-10 traps were collected to provide the sum of $\mathrm{Hg}$ for the first interval, but for most 5 minute intervals, a single trap was needed. In the end, to present all data in a simplified and similar manner, data were combined into five-minute intervals. In a few cases, where 10 minute collections were used (very low concentrations at the end of the purge time), the measured value was split into 5 minute parts, with $67 \%$ of the measured $\mathrm{Hg}$ on the first 5 minutes and $33 \%$ in the second five minutes. This factor was determined empirically from the data collected earlier by 5 minute intervals. In some cases, even with the very short purge times, the amount of $\mathrm{Hg}$ collected was slightly off scale. Since such samples can not be re-run, the peak height for these off-scale evens was estimated by the analyst by how long the pen was off scale (a surprisingly accurate technique when an highly experienced analyst is employed). These results are noted in the raw data sheets, and account for little variability overall, since any given data point is only a small part of the evasion curve.

In addition to the experimental measurements, two blanks were determined by integrating all of the $\mathrm{Hg}^{\circ}$ collected in 60 minutes by purging $\mathrm{Hg}$-free reagent water. These results were averaged and divided by 60 , to yield a very small blank of $0.0006 \mathrm{ng} / \mathrm{min}$ for the purging procedure, which was subtracted from 
the results prior to reporting and further calculations. The water samples were quantified for total $\mathrm{Hg}$ before and after the purging period, to allow quantification of a mass balance for each experiment. The initial water was also measured for $\mathrm{Hg}$ speciation (dissolved $\mathrm{Hg}, \mathrm{Hg}$ (II), and by implication from the no $\mathrm{SnCl}_{2}$ purging experiment, $\mathrm{Hg}^{\circ}$ ). These results showed that virtually all of the mercury in the WSRC samples is as $\mathrm{Hg}$ (II). The form of the $\mathrm{Hg}\left(\mathrm{NO}_{3}\right)_{2}$ spiked DIW samples was assumed to be at the spiked concentration, and all as $\mathrm{Hg}$ (II), but no measurements were made to confirm this.

Total Hg Analysis. After the samples were oxidized for at least 4 hours in their original bottles by the addition of $1.0 \%(\mathrm{v} / \mathrm{v})$ of $0.2 \mathrm{~N} \mathrm{BrCl}$ in $12 \mathrm{~N} \mathrm{HCl}$ (Bloom and Crecelius, 1983), they were analyzed according to EPA method 1631, as follows. A $50-125 \mathrm{~mL}$ aliquot of the acidified sample is placed into a clean Teflon bottle, and the $\mathrm{BrCl}$ oxidant was pre-reduced by the addition of $\mathrm{NH}_{2} \mathrm{OH}$. The pre-reduced solution is then poured into the purge vessel, and $\mathrm{SnCl}_{2}$ added to reduce the free $\mathrm{Hg}(\mathrm{II})$ to $\mathrm{Hg}^{\circ}$. The $\mathrm{Hg}^{\circ}$ is then purged from solution, and collected onto a gold coated sand trap (Bloom and Crecelius, 1983). After collection, the $\mathrm{Hg}$ on the gold trap is re-focused on a second "analytical" trap, by thermal desorption into a gas stream of pure argon. Finally, the $\mathrm{Hg}$ was thermally desorbed from the analytical trap into the CVAFS cell, where it was detected and quantified. For this analyses, full QC including an MD and MS/MSD for every 20 samples, certified reference material, and at least three method blanks per 20 samples were analyzed.

\section{Conclusion}

The results have been summarized into 5 minute intervals in the data tables. It is very clear that even the smallest amounts of Sn(II) will result in extremely fast reduction of $\mathrm{Hg}$ (II) to $\mathrm{Hg}^{\circ}$, meaning that for all of the $\mathrm{SnCl}_{2}$ addition experiments, the $\mathrm{Hg}$ evasion rate is simply a function of the purging rate. In the three experiments conducted at $22.8^{\circ} \mathrm{C}$, the mean $\mathrm{Hg}^{\circ}$ purge rate was $28.0 \pm 1.0 \%$ of the $\mathrm{Hg}$ present per volume of purge gas. For the single experiment at $0^{\circ} \mathrm{C}$, the rate fell to $19.1 \%$ per volume. In both deionized water and the ambient sample, virtually no $\mathrm{Hg}^{\circ}$ was evaded $(0.026 \%$ per volume in DI water, $<0.002 \%$ per volume in the actual sample) without the addition of $\mathrm{SnCl}_{2}$. Even at the lowest concentration of $\mathrm{Sn}$ (II) tried ( $1 \mu \mathrm{g} / \mathrm{L}=12: 1$ molar ratio of $\mathrm{Sn}$ to $\mathrm{Hg}$ ), the reduction kinetics appeared to be much faster than the purging kinetics. This is supported by WSRC field results showing the reduction reaction to be quantitative even at a 1:1 mole ratio. 


\section{Analytical Issues}

All analytical data generally showed good QA and coherence, and the data appears to be of high quality. One point that should be made clear is that in several instances, the $\mathrm{Hg}$ evaded from the purge vessel was so high as to result in an off-scale reading, and in a couple of other instances, a data point went missing due to a broken analytical trap, or missed sampling interval during the experiment. To allow a full accounting of the $\mathrm{Hg}$ purging, these compromised points (about $5-10 \%$ of the total number of collected data points, which averaged about 20 per experiment) were estimated, either from how long the chart pen appeared to be off scale (for slightly off scale points), or by calculation from the evasion rates from the surrounding data points (for missing data). This estimation procedure was necessary for completeness, since none of the points could be re-run (once you analyze a trap, the $\mathrm{Hg}$ is gone, there is no more "sample" to go back to). By doing so, complete purging curves were possible for each experiment. I do not feel that this procedure materially compromises the results, because each particular data point only contributes slightly to the whole curve, and so an error in its estimation is not significant, over all. As can be seen from the tables, over the six experiments conducted, mass balances averaged 97.1 $\pm 8.8 \%$ recovery of the expected $\mathrm{Hg}$, which is pretty good, since over 20 measurements went into each mass balance.

\section{References}

Bloom N.S. 1995 "Mercury as a Case Study of Ultra-Clean Sample Handling and Storage in Aquatic Trace Metal Research," Environmental Lab, March/April: 20

Bloom, N.S 1989. "Determination of Picogram Levels of Methylmercury by Aqueous Phase Ethylation, Followed by Cryogenic Gas Chromatography with Cold Vapor Atomic Fluorescence Detection." Can. J. Fish Aq. Sci. 46: 1131-1140.

Bloom, N.S and Fitzgerald, W.F. 1988. "Determination of Volatile Mercury Species at the Picogram Level by Low Temperature Gas Chromatography With Cold Vapor Atomic Fluorescence Detection." Anal. Chim. Acta. 208: 151161.

Bloom, N.S and Crecelius, E.A. 1983. "Determination of Mercury in Seawater at Sub-Nanogram per Liter Levels." Mar. Chem. 14: 49-59. 
Horvat, M., Bloom, N.S., and Liang, L. 1993. "A Comparison of Distillation with other Current Isolation Methods for the Determination of Methyl Mercury Compounds in Low Level Environmental Samples Part 2, Water" Anal. Chim. Acta, 282: 153.

Liang, L., Horvat, M., and Bloom, N.S. 1994. "An Improved Speciation Method for Mercury by GC/CVAFS After Aqueous Phase Ethylation and Room Temperature Precollection," Talanta 41: 371-379.

Bloom, N.S., 1993. "Ultra-Clean Sampling, Storage, and Analytical Strategies for Accurate Determination of Trace Metals in Natural Waters," Proceedings of the 16th Annual EPA Conference on Analysis of Pollutants in the Environment, EPA 821-R-94-001, Washington, DC, USA 


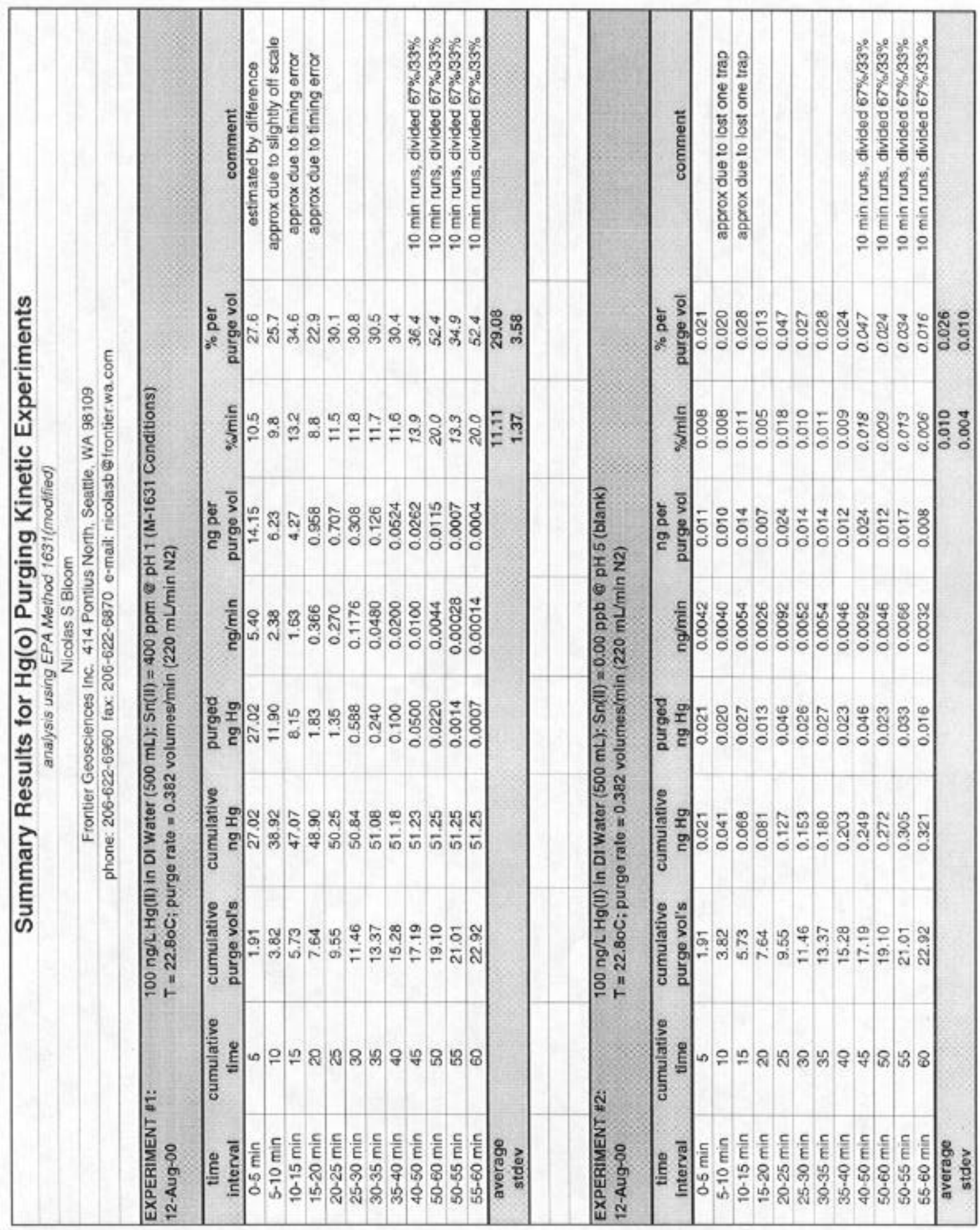




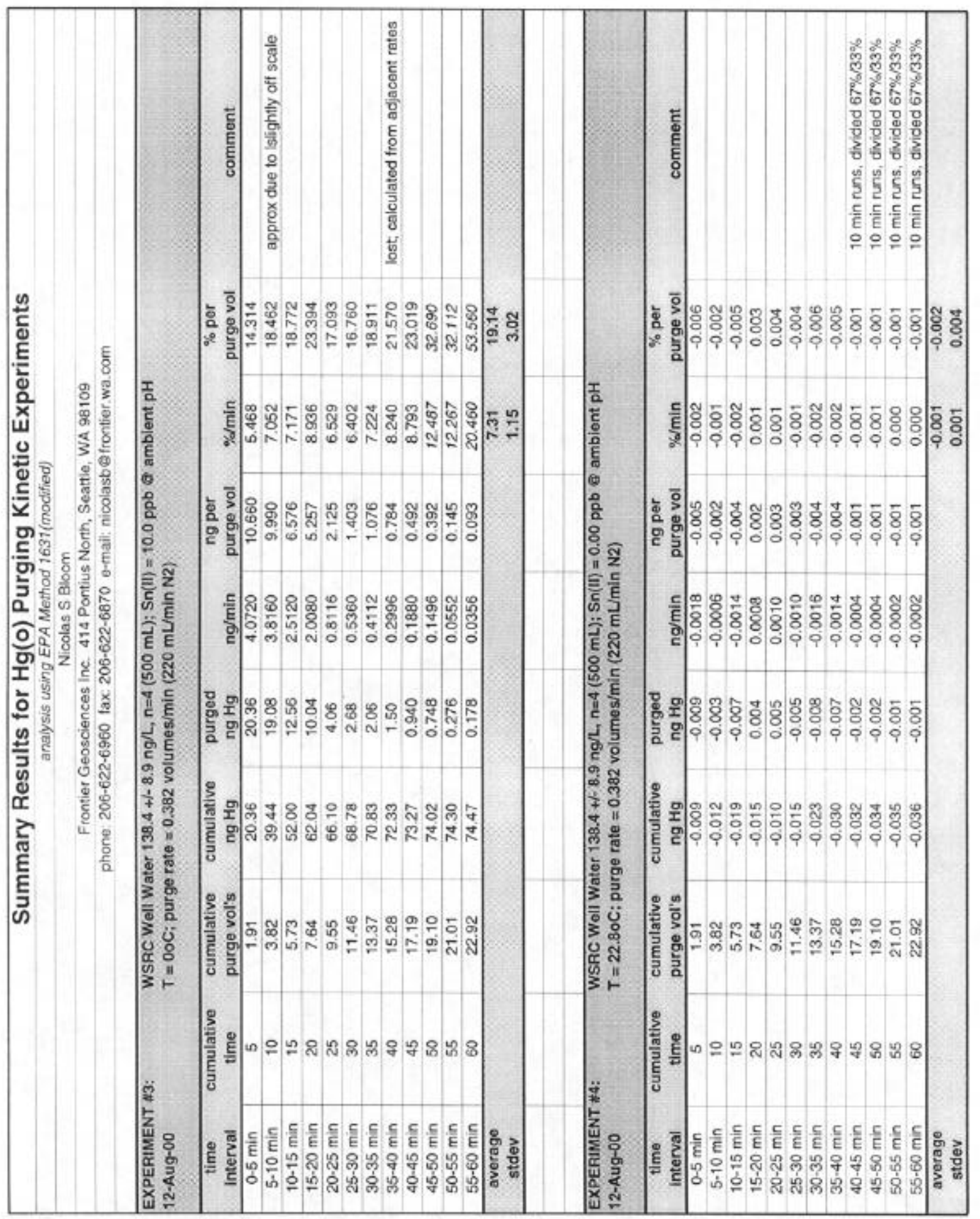




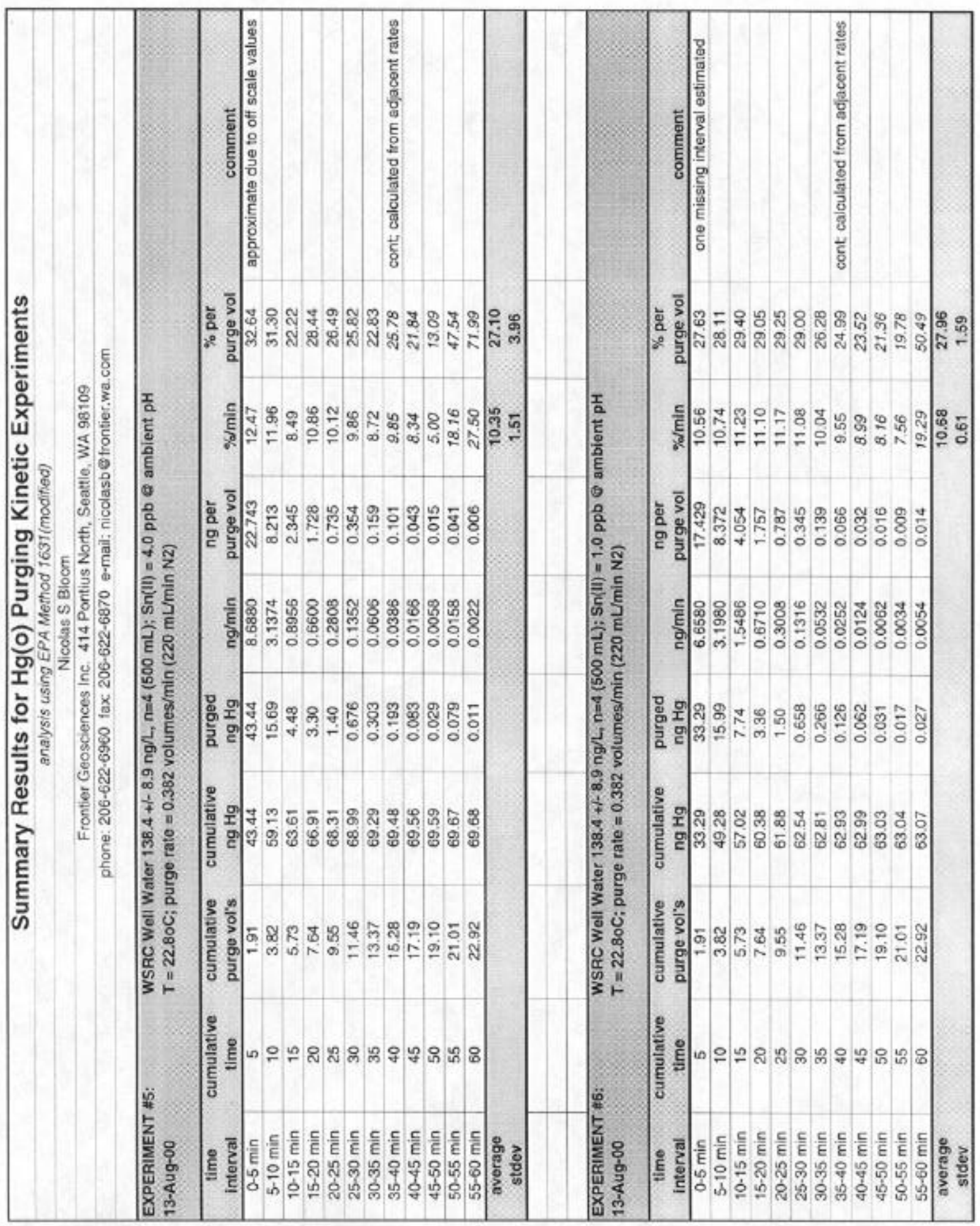




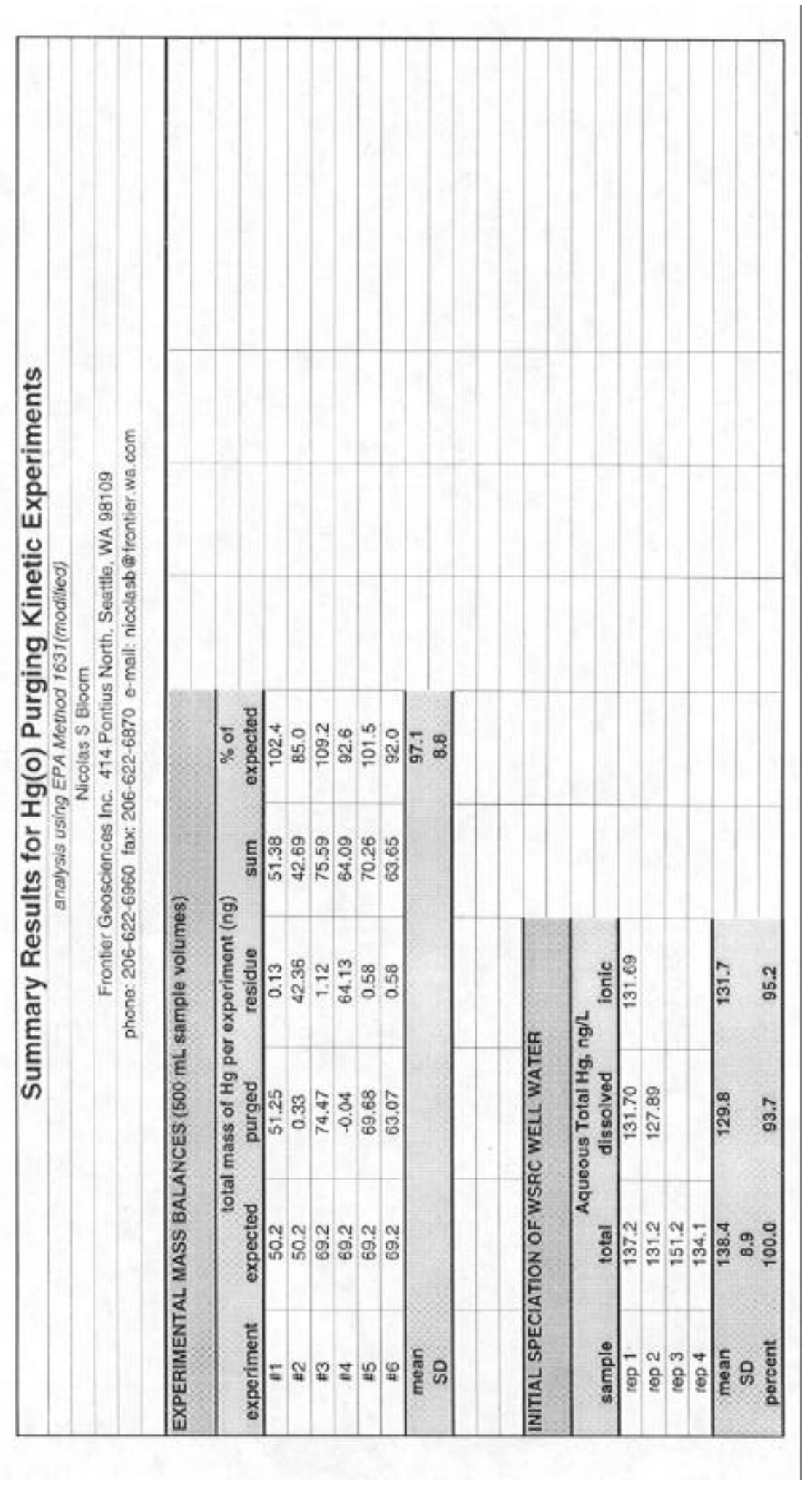

